G68.8: EC74/M38

\title{
The Massachusetts Health Care Industry: Pathways to the Future
}

Final Report April 1994

Task Foree on the Health Care Industry

$$
\text { OULECTION WENTS }
$$

$$
\text { Aisto } 0 \cdot 1994
$$

$$
\begin{aligned}
& \text { University of Massachuseits } \\
& \text { Depository Copy. }
\end{aligned}
$$

Governor's Council on Economic Growth and Technology

Council Leaderstaip:

Govermor

William $F$. Weld

\section{Lt. Governor}

A. Paul Cellucei

Sec. of Ecomomic Affaires Gloria Larson

Councill Chair Prof, Michael E. Porter
Task Force Chairs: Jerome H. Grossmain; $\mathbb{M}_{0} \mathrm{D}_{\text {. }}$ Ferdinand Colloredio-Mansfeld

Repont prepared by: Dana Gellb Safran, SG.D. Jennifer Prah Ruger, M.SG。

The Health Dnstifturte New England Miedical Center 750 Wastingitur Streel, Box 345

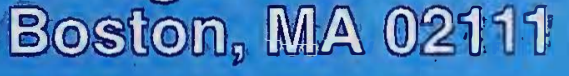

(617) 636-8600 
Digitized by the Internet Archive in 2013 


\section{Task Force Membership}

Chairmen:

Jerome H. Grossman, New England Medical Center

Ferdinand Colloredo-Mansfeld, Cabot Partners

Kathleen Angel

Digital Equipment Corporation

Stuart Altman

Brandeis University

Dennis Austin

Raytheon Corporation

Hamis Berman

Tufts Associated Health Plan

Ruth Blodgett

Berkshire Medical Center

David Blumenthal

Massachusetts General Hospital

David M. Bray

Hanvard Medical School

Lynne E. Browne

Federal Reserve Bank of Boston

Howard E. Cox, Jr.

Greylock Management Corporation

Diane Duval

Lotus Development Corporation

Larry Dwyer (adjunct member)

Boston Department of Public Health

Robert Fanning

Beverly Hospital
Elmer Freeman

Whittier St. Neighborhood Hth Ctr

Robert S. Galvin

General Electric Company

Michael Hooker (adjunct member)

University of Massachusetts

Don Kepert

Chartwell Home Therapies

Adela Margules

Bowdoin St. Hth Ctr

Edie Mas

Gtr Lawrence Comm Hth Ctr

Suzanne Mercure

Bull HN Information Systems, Inc

David Mulligan (adjunct member)

Mass. Dept. of Public Health

Joseph P. Newhouse

Harvard Medical School

Jay B. Pieper

Brigham \& Women's Hospital

Daniel T. Roble

Ropes \& Gray

Wemer Schuele

Texas Instruments, Inc. 



\section{Task Force Membership - cont'd}

Jackie Jenkins Scott

Dimock Community Health Center

Alan Solomont

ADS Group

Howard Spivak

New England Medical Center
Elaine Ullian

Faulkner Hospital

Christopher T. Walsh

Dana Farber Cancer Institute

William Van Faasen

Blue Cross and Blue Shield 

Task Force on the Health Care Industry

\author{
Mission Statement \\ October 1993
}

As part of his Council on Economic Growth and Technology, Governor William F. Weld has commissioned a Task Force on the Health Care Industry to address issues surrounding the present and future role of that industry in the maintenance and growth of the Massachusetts economy. In addition to its role advising the Governor, it is expected that the task force will, from time to time, make its positions known to the Congressional delegation. The task force will be jointly chaired by Ferdinand Colloredo-Mansfield, Chairman of the Board of Massachusetts General Hospital and Jerome H. Grossman, M.D., President of New England Medical Center. The task force will include representatives from the health care industry, Massachusetts businesses and the academic research community, whose combined expertise will inform its work on the following three objectives:

First, the task force will address issues pertaining to the present and future role of the health care industry as a vital element of the Massachusetts economy. Economic and political pressures nationally and locally continue to require adaptation and realignment of the health care delivery sector. The task force will recommend to the Governor strategies by which to foster the appropriate restructuring and development of the Massachusetts health care sector while maintaining and advancing its position as a national and international leader in health care delivery and research.

Second, the task force will address key concerns regarding the relationship between the health care sector and other elements of the Massachusetts economy. With representation from the Massachusetts business community along with the health care delivery and research communities, the task force will be well positioned to identify the impact of health care costs on state businesses' competitive position and to recommend strategies through which to address these pressures.

Lastly, the task force will monitor national health care reform legislation and evaluate its impact on the Massachusetts health care industry and the economy at large. In this capacity, the task force will propose strategies by which to implement any nationally mandated reforms within a framework that supports and fosters all sectors of the economy and maintains the Commonwealth's position as a global leader in health care delivery and research. 



\section{Acknowledgments}

The authors would particularly like to acknowledge Richard Averbuch (Massachusetts Business Roundtable) and Jane Snedin Little (Federal Reserve Bank of Boston) for their tremendous contributions to this work.

We also thank the following people for the information they provided to assist this effort: Andrew Dreyfus (Massachusetts Hospital Association), Michelle Garvin (Ropes \& Gray), John May (Massachusetts Association of HMOs), Robert J. Blendon (Hanvard School of Public Health), Karen Donelan (Hanvard School of Public Health), John Holohan (Urban Institute), Shruti Raji (Urban Institute), Jeffrey Ritter (Department of Medical Security), Shannon Linde (MBA Companies), Lisa M. Carroll, (Small Business Service Bureau, Inc.), Sandra Christensen, (Congressional Budget Office), Chris Bergston (Group Health Association of America), Judy Hemming (Blue Cross/Blue Shield), Anthony J. Santangelo, Jr. (Boston Organization of Teaching Hospital Financial Officers), Hilary E. Cooklin (Massachusetts Hospital Association), Scot T. Keefe (Massachusetts Taxpayers Foundation, Inc.), Lise Federman (Massachusetts Department of Health and Human Services), Holly Fitzgerald (New England Medical Center), Carolyn Yordon (Greater New York Hospital Association), Sally Fogerty (Massachusetts Department of Public Health), Jacob A. Herman (Rand Corporation), Denise Hammon (Association of Independent Colleges and Universities in Massachusetts), John C. Hoy ( New England Board of Higher Education), Janice Bourque (Massachusetts Biotechnology Council), Richard M. Knapp (Association of American Medical Colleges), Michael Jud ( Federal Reserve Bank of Boston), Kevin G. Serrin (Association of American Medical Colleges), Nancy Avies (Baruch College, The City University of New York), Barbara Rockett (Newton-Wellesley Hospital), Jeffrey M. Kichen (Massachusetts Medical Society), Kathleen Hennessy Amirault (Massachusetts Department of Health and Hospitals), David P. Smith (Massachusetts Hospital Association), Jim Hunt (Massachusetts League of Community Health Centers), Tim Burgers (Home Health Care Association of Massachusetts, Inc.), Petra Langer (Massachusetts Federation of Nursing Homes), Julie Pinkham (Massachusetts Nurses Association), Andrew Levine (Massachusetts Department of Public Health), Robert Restuccia (Health Care For All), Mary Sullivan (Bureau of Labor Statistics), Frances M. Durkin (Massachusetts Hospital Association), A Blostin (US Department of Labor), Elizabeth Olmsted Teisberg (Harvard Business School), Judith ShindulRothschild (Boston College School of Nursing), John Erb (Foster Higgins), Matthew J. Siegel (Massachusetts Division of Insurance), James F. Kocke (Greater Boston Chamber of Commerce), Edward H. Pendergast (Pendergast \& Company), David C. Harlow (Massachusetts Department of Public Health), David Lee (Minnesota Hospital Association), Teri Micelli (American Hospital Association), Sara J. Singer (Stanford Graduate School of Business), Kathy Swart (Hanvard School of Public Health).

The authors also thank Jennifer Lin, Maria McCarthy, Nathan Lockwood and Aaron Lippert for their assistance with the preparation of tables, figures and text for this report. 



\section{TABLE OF CONTENTS}

EXECUTIVE SUMMARY

INTRODUCTION

HEALTH CARE EXPENDITURES: ACCOUNTING FOR HIGH COSTS IN MASSACHUSETTS $\ldots \ldots \ldots \ldots \ldots \ldots \ldots \ldots \ldots \ldots \ldots \ldots \ldots \ldots \ldots$

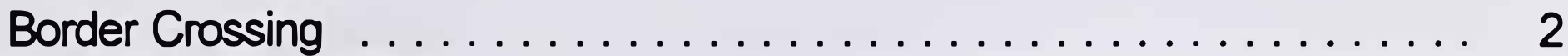

Care of the Uninsured $\ldots \ldots \ldots \ldots \ldots \ldots \ldots \ldots \ldots \ldots \ldots, 2$

Health Care Delivery Infrastructure $\ldots \ldots \ldots \ldots \ldots \ldots \ldots \ldots \ldots, 4$

Health Care Delivery Patterns $\ldots \ldots \ldots \ldots \ldots \ldots \ldots \ldots \ldots .6$

Personal Income ................................. 9

Rich Benefit Packages ......................... 13

Section Summary $\ldots \ldots \ldots \ldots \ldots \ldots \ldots \ldots \ldots \ldots \ldots \ldots$

INSURING THE UNINSURED $\ldots \ldots \ldots \ldots \ldots \ldots \ldots \ldots \ldots \ldots \ldots$

Estimated Cost of Providing Coverage to the Uninsured . . . . . . . . . 17

Strategies for Attaining Universal Coverage ............... 20

COST CONTROL IN THE HEALTH CARE SECTOR . . . . . . . . . . . . 27

Cost Control Through Market Competition . . . . . . . . . . . . . 29

HEALTH SYSTEM REFORM AND MASSACHUSETTS BUSINESSES . . . . . . . 35

Health Care as a Cost of Doing Business in Massachusetts . . . . . . . . 35

A Business Perspective on Key Health Policy Issues ........... 36

CHARACTERISTICS OF MASSACHUSETTS' HEALTH CARE DELIVERY

SYSTEM \& PROJECTED IMPACT OF HEALTH SYSTEM REFORM . . . . 39

Health Care Delivery Personnel $\ldots \ldots \ldots \ldots \ldots \ldots \ldots \ldots \ldots . \ldots . \ldots$

Health Care Delivery Facilities $\ldots \ldots \ldots \ldots \ldots \ldots \ldots \ldots \ldots .48$

HEALTH-RELATED RESEARCH AND EDUCATION $\ldots \ldots \ldots \ldots \ldots \ldots .54$

Health-Related Research . . . . . . . . . . . . . . . . . . . . . . 55

Graduate Medical Education $\ldots \ldots \ldots \ldots \ldots \ldots \ldots \ldots \ldots \ldots .65$

Summary Comment . . . . . . . . . . . . . . . . . . . . 58

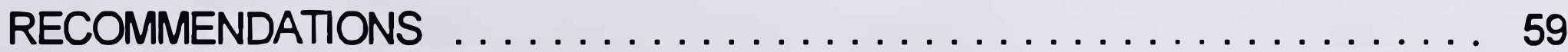

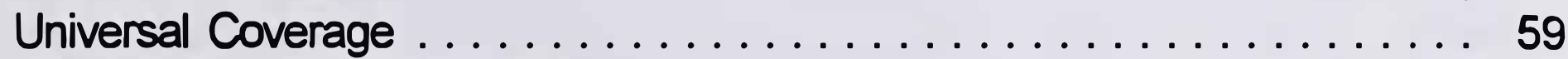

Non-Group Insurance Reform . . . . . . . . . . . . . . . . . . . . . . 59

Essential Community Providers $\ldots \ldots \ldots \ldots \ldots \ldots \ldots \ldots .60$

Health Alliances $\ldots \ldots \ldots \ldots \ldots \ldots \ldots \ldots \ldots \ldots \ldots \ldots, 61$

Cost Control ...............................61

Job Training Funds $\ldots \ldots \ldots \ldots \ldots \ldots \ldots \ldots \ldots \ldots \ldots \ldots \ldots, 61$

Graduate Medical Education $\ldots \ldots \ldots \ldots \ldots \ldots \ldots \ldots \ldots \ldots 62$

Health-Related Research . . . . . . . . . . . . . . . . . . . . . . 62 


\section{EXECUTIVE SUMMARY}

The Commonwealth of Massachusetts is endowed with a health care industry that is arguably the finest in the nation and most definitely a leader worldwide.

Massachusetts is renowned nationally and internationally for the technical excellence of its health care delivery system. The Commonwealth leads the nation in healthrelated research, bringing advances in knowledge, treatments, systems and technologies for improving human health. And Massachusetts institutions for medical education have an unsurpassed reputation for excellence.

Yet this wealth of resources in the health care sector imposes costs on the Massachusetts economy that must be recognized and addressed. At a time when gaining control of health care costs has become a national priority, Massachusetts must look to strategies for restraining health care expenditures while allowing its health care sector to retain its position of distinction.

Health Care Expenditures in Massachusetts. The Commonwealth currently spends more per capita on health care than any other state. In 1991, Massachusetts spent $\$ 14.4$ billion - $\$ 2400$ per capita - on hospital care, physician senices and prescription drugs. While these figures do not take into account care that is provided to out-of-state residents, adjustment for these factors does not substantially reduce per capita expenditure estimates.

High expenditures appear to be primarily attributable to three factors: (1) high personal income, (2) a large health care delivery infrastructure, and (3) utilization pattems that feature more frequent inpatient care, a large portion of which is delivered in urban medical centers.

Each of these represents a double edged sword with respect to the Commonwealth's economy overall. Our relatively high personal income, while contributing to high spending and high health care costs, also reflects the predominance of a highly skilled, well educated labor force. The large health care infrastructure represents a source of employment for more than 10 percent of Massachusetts workers. And while the utilization patterns associated with large urban teaching facilities raise the cost of medical care, they also make available to Massachusetts residents care that is nationally and intemationally renowned for its quality and innovation.

Health Care Cost Inflation. Massachusetts' position with respect to containing health care cost inflation is more favorable than that of its overall health spending. Between 1980 and 1991, while health care costs soared at rates more than twice inflation, Massachusetts retained annual rates of health spending growth on par with the national average and below many of its leading competitors. And recently, rates of growth have been substantially reduced, approaching the general inflation rate. In 1994, Massachusetts' leading HMOs' premiums increased by an average of 5 percent. 

Indemnity plan premium increases were also the lowest in recent history.

Health Care Costs as a Burden on Business. High health care costs are only one of a constellation of factors that Massachusetts employers say puts them at a competitive disadvantage. High wage rates, workers' compensation rates, unemployment insurance rates, energy costs, state tax policy and state regulatory policy combine with high health care costs to create a difficult business climate.

Thus, many businesses encourage reform that will bring Massachusetts' health care costs more in line with the national average. However, the rate of growth in health care costs appears to be of comparable importance to Massachusetts employers. Business leaders suggest that attaining predictable rates of increase in health care costs, at or below the rate of inflation, must be a priority.

Toward that end, recent experience with containing health care cost inflation (described above) are encouraging. However Massachusetts businesses remain concemed about the aggregate level of spending.

Universal Coverage. An estimated 11 percent of Massachusetts residents - 664,000 persons - lack health insurance. This rate is substantially below the national average (15 percent). Nonetheless, task force members from the business and health care sectors alike are unanimous in their view that universal health insurance coverage must be a prionity of health care reform. In addition to considerations of equity and social concem, issues of cost shifting and uncompensated care related to uninsurance are of high concem to the business and health care sectors.

While, some form of mandate is regarded as necessary to assure universal coverage, task force members are not united in their view as to the appropriate nature of such a mandate. Strategies for attaining universal coverage fall generally into three categonies: (1) employer mandate, (2) individual mandate, and (3) single payer. The final task force report details political and administrative bamiers associated with each and, where possible, estimates the associated public and private sector costs.

In addition, the final task force report will estimate new expenditures associated with providing universal coverage. Estimates will reflect new costs associated with coverage and care, taking into account the cost of care currently provided to uninsured. Note, that the distribution of these costs - business versus individual versus govemment - will depend substantially on which universal coverage strategy is adopted.

Cost Control Through Market Competition. Recent gains in restraining the growth of health care costs are believed attributable to a combination of employer pressure and anticipated national reforms. Task force members are united in their feeling that the 1990s have marked a decisive tuming point with respect to health care costs. 


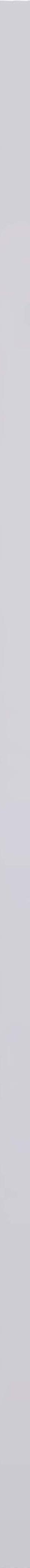


They maintain that the premium inflation of the 1980s will not likely recur as employers will continue firm negotiation with insurers, vigilant to prevent rates of premium inflation like those of the previous decade.

In this context, many employers express concems regarding potential requirements for participation in regional purchasing alliances. While purchasing cooperatives are regarded as a useful tool in the small group insurance market, it is unclear whether their extension more broadly will facilitate or hamper market competition. The Jackson Hole Group, led by the originators of managed competition theory, maintains that regional alliances were never intended for universal participation. Many large and small Massachusetts companies express the importance of allowing large employers to remain outside of the alliance. Large employers are seen as senving a valued function in the market, helping to drive and advance benefit design, innovation and cost control.

Purchasing Cooperatives. Two working groups of this task force - one comprised of Massachusetts businesses and one comprised of Massachusetts insurers - each recommend that employers with more than 100 employees be excluded from any required alliance participation. The Clinton health care reform proposal mandates participation among businesses of 5000 or fewer employees. Both in Massachusetts and nationwide, less than 2 percent of businesses have between 101 and 5000 employees. Ninety-four percent of Massachusetts firms have 100 or fewer employees.

Without reform or repeal of the federal Employee Retirement and Income Security Act (ERISA), state law cannot require alliance participation. Without mandatory alliance participation, regardless of the firm size chosen for alliance participation, states must adopt measures to predude risk segmentation in the small group market. Without such a strategy, the potential for effective market competition through the alliance will be negated as small groups with a favorable health rating will seek coverage outside of the alliance. One proposed strategy would require uniform premium rating rules applied to small groups regardless of alliance participation.

There are differing opinions, nationally and locally, regarding the appropriate responsibilities and govemance structure for purchasing alliances. The task force recommends that any alliances be nonprofit corporations with employer and consumer boards of trustees, reflecting their primary function of acting as an agent for the consumer. With respect to responsibilities for premium collection and distribution, the task force recommends that funds not pass through the alliance. Rather, a bank or investment company, contracted through the alliance, is suggested as the appropriate mechanism. Two tasks unanimously viewed as within the alliance's punview are risk adjustment and information dissemination.

The appropriate number of purchasing alliances for Massachusetts will depend, in part, on the expected scope of employer participation statewide. The Jackson Hole 
Group recommends that each alliance represent at least 300,000 individuals and between 30 and 50 percent of the market.

Impact of Reform on Health Care Delivery Sector Employment. The health care delivery sector - the largest of the four sectors that comprise the health care industry - employs 10.5 percent of Massachusetts' total workforce. This figure represents a lower bound as U.S. labor statistics do not permit a full accounting of persons employed in health-related research and education. And while Massachusetts lost 400,000 jobs since 1988 , health sector employment increased by 40,000 jobs.

However, growth in health sector employment appears to be slowing. Data for the first nine months of 1993 suggest an annual job growth rate of 2.9 percent, compared with an average of 3.6 percent for each of the preceding five years. And substantial job loss over the next several years is believed likely. The majority of job curts are expected to come from hospitals, the sub-sector that currently employs more than half of all health care delivery personnel.

The magnitude of job loss is exceedingly difficult to project as there is no previous experience with downward employment trends in this industry. For estimation purposes, this task force projected employment changes as a function of potential hospital bed closures. Based on this methodology, the task force estimates that between 6,500 and 30,000 hospital sector jobs will be lost over the coming period of health care system reform. These estimates correspond to 1,440 and 7,783 hospital bed closures, respectively.

A portion of hospital jobs are expected to be re-absorbed into other areas of the health care industry. In particular, increased demand is expected in ambulatory and subacute care settings. However, lower compensation and substantially different dinical responsibilities may impede these shifts. Job retraining will be essential during this time of transition - both for those moving from hospital jobs to other health care settings and for those seeking employment outside of the health care industry.

Essential Community Providers. Essential community providers, broadly defined, include institutions and organizations that provide care for populations whose social, financial and/or geographic position otherwise impedes acoess to timely and effective care. Task force members note that without purposeful attention to the unique role (and associated costs) of essential community providers, the populations they serve may be left further disadvantaged by health system reform.

Health system reform is expected to bring essential community providers into direct competition with other provider organizations who might choose to locate offices in these communities. While enhanced choice may greatly benefit these populations, price cannot be the sole determinant of providers' eligibility for senving these populations. Qualification must indude evidence of providers' capacity to deliver the 

spectrum of interrelated social and health services required in providing effective care to these populations.

To adequately compensate providers for these added costs of care, senvices should be supported either through direct payments to essential community providers or through nisk adjustment formulae that adequately reflect these added costs.

Health-Related Research. Massachusetts remains a national and global leader in health-related research. In 1993, through the National Institutes of Health (NIH) alone, Massachusetts received an estimated $\$ 854$ million in federal research money.

Additional monies came through other federal sources, private foundations and, to a small degree, state funds.

Competing for federal and private foundation funds, Massachusetts continues to surpass the performance of nearly every other state. In 1993, Massachusetts alone received more than half of all NIH funds awarded to hospitals. Five Massachusetts hospitals accounted for 80 percent of these monies. Massachusetts universities and research institutions also fared well - with only Califomia and New York gaining more $\mathrm{NIH}$ funds in these categories.

Projected changes in the availability of and mechanisms for research funding are of concem. Proposed changes may reduce the amount of funds available and may hinder the viability of many Massachusetts research enterprises. In this context, members of the research community stress the need for an increased state role in supporting research through fund raising assistance or capital investment. These could boost Massachusetts' ability to continue to compete effectively for federal and private research funds. If Massachusetts researchers fail to compete effectively for these funds, other states will gain both the monies and the spin-off products and industries that currently benefit our economy.

Graduate Medical Education. Massachusetts has, arguably, the finest medical education and training system nationally and worldwide. The infrastructure supporting this system indudes four accredited medical schools, 52 hospitals with accredited residency training programs, and 19 academic medical centers. In 1993, Massachusetts trained 3,027 medical residents - 3.5 percent of the U.S. total. The state received an estimated $\$ 808$ million in revenues for graduate medical education.

National health system reform is expected to drastically reduce rates of payment for graduate medical education (GME). A coalition of Massachusetts teaching hospitals found that the level of GME funding proposed by the Clinton plan would result in a $\$ 1.9$ billion shortfall to Massachusetts teaching hospitals between 1996 and 2000. The largest losses are due to proposed changes in rates of payment for indirect medical education (IME). 

Task force members find compelling evidence that the rationale for reduced IME payments is flawed. In large part, IME funds support the expenses associated with the disproportionate share of severely ill patients cared for in teaching hospitals. This aspect of teaching hospital care is not expected to lessen - and may increase during health system reform. Further reductions in the IME payment rate threaten the viability of medical centers that have been a unique and enduring asset to the Commonwealth's health care system, and that have, in large part, eamed Massachusetts' national and intemational renown for excellence in medical care.

Recommendations. Owing to the diversity of interests represented in the task force membership, there are only a small number of issues about which the group achieved consensus. These induded the following:

- Universal health coverage must be a principal goal of health system reform.

- Non-group insurance reform is needed to stabilize and assure the availability of coverage to persons who must purchase insurance individually.

- Standards of care for special populations and corrmunities must be established to assure that providers competing to provide their care adequately attend to the full spectrum of senvices required.

- Health care purchasing alliances, if established, should be nonprofit corporations with consumer and employer boards of trustees, reflecting their primary function as an agent for the consumer.

- To the greatest extent possible, health care purchasing alliances should contract to the private sector to perform essential functions. In particular, responsibility for premium collection and distribution should be contracted to a bank, investment company or similarly qualified organization.

- If health alliance participation remains voluntary, identical premium rating rules must be imposed within and outside of the alliance.

- The Commonwealth should not undertake any regulatory steps toward health care cost control at this time. The need for regulatory cost control measures should be reconsidered in three to five years.

- A portion of state funds for job retraining and education should be directed to assist individuals displaced during health system reform.

- The Commonwealth should press to retain current federal indirect research cost allowances and encourage rates of increase in federal research funding that are at least up to the rate of inflation. 
- Massachusetts should work hard to oppose federal reductions in funding for graduate medical education. Proposed reductions in the indirect medical education payment rate should be particularly resisted. 



\section{INTRODUCTION}

The Commonwealth of Massachusetts is endowed with a health care industry that is arguably the finest in the nation and most definitely a leader worldwide.

Massachusetts is renowned nationally and internationally for the technical excellence of its health care delivery system. The Commonwealth leads the nation in healthrelated research, bringing advances in knowledge, treatments, systems and technologies for improving human health. And Massachusetts institutions for medical education have an unsurpassed reputation for excellence.

Yet this wealth of resources in the health care sector imposes costs on the Massachusetts economy that must be recognized and addressed. Growth in the health care sector cannot be permitted to occur to the exdusion of other Massachusetts businesses. At a time when gaining control of health care costs has become a national priority, Massachusetts must look to strategies for restraining health care expenditures while allowing its health care sector to retain its position of distinction.

In this report to the Governor's Council on Economic Growth and Technology, the Task Force on the Health Care Industry examines the status of health care delivery, research and education as both assets and costs to the Massachusetts economy. The task force explores the present and historic position of these sectors within the economy and attempts to account for the historically high health care expenditures in the Commonwealth. The task force also evaluates the potential mechanisms through which to attain universal coverage and estimates the associated costs. The task force examines various proposed mechanisms for cost control. Finally, the task force evaluates the economic impact that various proposed health care reform strategies might have on the quality and cost of health care delivery, research and education in Massachusetts.

\section{HEALTH CARE EXPENDITURES: ACCOUNTING FOR HIGH COSTS IN MASSACHUSETTS}

Massachusetts has the dubious distinction of spending more per capita on health care than any other state in the nation. In 1991, Massachusetts spent $\$ 14.4$ billion $\$ 2400$ per capita - on hospital care, physician senvices and prescription drugs. ${ }^{1}$

State-level estimates of health spending differ widely due to variability in the data sources, methodology, and components induded in expenditure totals. This report draws expenditure data from the U.S. Health Care Financing Administration (HCFA). HCFA provides consistently defined state-level data for individual states and the U.S. overall. 

Table 1 reveals Massachusetts' spending position relative to the United States overall and relative to three groups of competitor states - other New England states (CT, ME, $\mathrm{NH}, \mathrm{RI}, \mathrm{VT})$, high technology states (CA, MD, NC, TX, WA) and large industrial states (FL, IL, MI, NJ, NY, OH, PA). Throughout this report, these three groups of states are used for comparative purposes as they represent Massachusetts' key competitors in the national economy.

State-level health care expenditure data indicate that Massachusetts spends approximately $\$ 500$ more annually per capita on health care than other states.

Following, we examine the respective role of several factors that may contribute to higher health care expenditures at the state level.

Border Crossing. An important methodological weakness of state-level health expenditure data is that they do not account for care provided in each state to out-ofstate residents. Expenditure totals include care provided to those who travel to the state to receive care or who become ill while visiting. To the extent that a state is a net "exporter" of care (i.e., providing more care to non-residents than other states provide to its residents), state-level expenditure data will be distorted. The best available data on border crossing and health care use indicate that Massachusetts is one of a very few states that are net "exporters" of care. Other export states inctude Califomia, Pennsylvania, North Carolina, Texas and Forida.

However, despite Massachusetts' position as a net exporter of care, a correction factor applied to account for health care border crossing does not substantially alter the Commonwealth's health expenditure position. Per capita expenditures remain approximately $\$ 440$ above the national average.

Care of the Uninsured. In considering a state's total health expenditures, it is useful to examine the portion of the state's population that lacks health insurance. A high number of uninsured is presumed to deflate total health expenditures as the uninsured tend to use fewer health senvices over a given period. A methodology developed by the Congressional Budget Office, based on results of the RAND Health Insurance Experiment, estimates that the uninsured use approximately 64 percent of the services used by insured individuals. ${ }^{2}$ These estimates adjust for demographic and health status differences. The results take into account the fact that the uninsured tend to delay health care use until a time of medical crisis, causing senvices to be obtained in a high cost setting under intensive conditions.

Note that although total population expenditures may be reduced by the presence of uninsured, high rates of uninsured tend to have an inflationary effect on health care prices and premiums. This occurs as providers pass on the cost of uncompensated care to those with private insurance coverage (i.e. cost shifting). 

Table 1: Annual Health Care Expenditures ${ }^{a}$, Dollars per Capita - United States, Massachusetts, and Leading Competitor States

\begin{tabular}{l|c}
\hline Geographical Area & Health Care Expenditures per Capita (\$) \\
\hline United States & 1,900 \\
\hline Massactusetts & 2,400 \\
\hline Other New England States & \\
\hline Connecticut & 2,100 \\
Maine & 1,600 \\
New Hampshire & 1,700 \\
Rhode Island & 1,900 \\
Vermont & 1,500 \\
High Technology States & \\
\hline California & 2,000 \\
Maryland & 1,900 \\
North Carolina & 1,700 \\
Texas & 1,800 \\
Washington & 1,700 \\
Large Industrial States & \\
Forida & 2,100 \\
Illinois & 1,900 \\
Michigan & 1,900 \\
New Jersey & 1,900 \\
New York & 2,100 \\
Ohio & 1,900 \\
Pennsylvania & 2,100 \\
\hline
\end{tabular}

Source: Expenditure data - Levit et al, Health Affairs 1993;12(3):7- 26. Population data - World Almanac and Book of Facts, 1993.

a Health care expenditures include expenditures for hospital care, physician services and prescription drugs purchased in retail outlets. This represents approximately 70 percent of total personal health care expenditures. The data exclude dental services, vision care, and long-term care senvices, which comprise the remaining 30 percent of expenditures personal health care expenditures. 

Massachusetts' rate of uninsured is low relative to the national average. Approximately 13.2 percent of non-elderly (age <65) Massachusetts residents are uninsured, compared with approximately 16.6 percent nationally. We consider nonelderly persons because citizens aged 65 and over receive federal Medicare coverage. Table 2 indicates Massachusetts' position relative to the three groups of competitor states. Note Massachusetts' rate of uninsured is about average for New England states, but that New England has low rates of uninsured overall. Among competitor states, uninsurance appears most prevalent in the high technology states, particularly Texas, Califomia and Washington.

Based on these factors, we conclude that the rate of uninsured in Massachusetts is unlikely to have a large impact on the state's relative health expenditure position.

Health Care Delivery Infrastructure. Health care spending has been observed to increase with the size of a state's health care delivery infrastructure. ${ }^{3}$ In general, the richer the state's resources in health care delivery facilities and personnel, the higher the observed expenditures." The GAO cites Massachusetts large health care delivery infrastructure as one of the key factors contributing to the state's high health care expenditures. ${ }^{3}$

The available data support the view that Massachusetts has a larger health care delivery infrastructure than its competitor states. Health care delivery sector employment represents 10.3 percent of total employment in the Commonwealth. Among its competitor states, only Rhode Island has a higher rate of health care sector employment than Massachusetts (table 3 ). The number of physicians per capita in Massachusetts is unsurpassed by its competitors states and is 50 percent above the national average (table 4). In addition to its wealth of health care delivery personnel, Massachusetts health care delivery facilities outnumber those of many of its competitors. Table 5 indicates that the number of hospital beds per capita in Massachusetts is higher than in the other New England states (except Maine) and higher than in the five high technology states. The large industrial states (except Michigan) have more beds per capita than Massachusetts.

The observed relationship is often discussed as evidence of "induced demand", wherein the medical industry is said to manipulate demand for services in response to extemal efforts to control expenditures. Theories of induced demand remain controversial and insufficiently documented. For purposes of this report, we discuss the relative size and structure of Massachusetts health care infrastructure, recognizing this as an important contributor to overall health expenditures, but not endorsing any point of view with respect to the mechanisms through which health care supply affects health care expenditures. 

Table 2: Percent of Non-Elderly Population Uninsured - United States, Massachusetts, and Leading Competitor States

\begin{tabular}{l|c}
\hline Geographical Area & Uninsured Non-Elderly \\
\hline United States & $16.6 \%$ \\
\hline Massachusetts & $13.2 \%$ \\
\hline Other New England States & \\
\hline Connectiaut & $8.8 \%$ \\
Maine & $13.1 \%$ \\
New Hampshire & $11.5 \%$ \\
Rhode Island & $12.3 \%$ \\
Vermont & $14.8 \%$ \\
High Technology States & \\
\hline California & $21.7 \%$ \\
Maryland & $15.5 \%$ \\
North Carolina & $17.8 \%$ \\
Texas & $25.3 \%$ \\
Washington & $21.4 \%$ \\
Large Industrial States & \\
\hline Florida & $23.5 \%$ \\
Illinois & $13.5 \%$ \\
Michigan & $10.5 \%$ \\
New Jersey & $12.7 \%$ \\
New York & $14.7 \%$ \\
Ohio & $12.2 \%$ \\
Pennsylvania & $9.4 \%$ \\
\hline
\end{tabular}

Source: $\quad$ Employee Benefits Research Institute, Sources of Health Insurance and Characteristics of the Uninsured: Analysis of the March 1992 Current Population Sunvey. January 1993. 

Table 3: Health Sector Employment as a Percent of Total Employment, 1992 United States, Massachusetts, and Leading Competitor States

\begin{tabular}{l|c}
\hline Geographical Area & Health Sector Employment \\
\hline United States & $7.9 \%$ \\
\hline Massachusetts & $10.3 \%$ \\
\hline Other New England States & \\
\hline Cornectiart & $9.2 \%$ \\
Maine & $9.0 \%$ \\
New Hampshire & $8.4 \%$ \\
Rhode Island & $10.8 \%$ \\
Vermont & $9.1 \%$ \\
High Technology States & \\
\hline California & $6.8 \%$ \\
Maryland & $8.2 \%$ \\
North Carolina & $5.6 \%$ \\
Texas & $7.3 \%$ \\
Washington & $7.4 \%$ \\
Large Industrial States & \\
Forida & $8.8 \%$ \\
Illinois & $10.1 \%$ \\
Michigan & $8.8 \%$ \\
New Jersey & $8.3 \%$ \\
New York & $8.1 \%$ \\
Ohio & \\
Pennsylvania & \\
\hline
\end{tabular}

Source: U.S. Bureau of Labor Statistics, ES202 data tape, 1992 (unpublished data)

b Health sector employment indudes general and specialty hospitals, offices and dinics of medical doctors, dentists and other health practitioners, medical and dental laboratories, nursing and personal care facilities, nursing homes and home health care. 

Table 4: Non-Federal Physicians ${ }^{c}$, per 1000 Population - United States, Massachusetts, and Leading Competitor States

\begin{tabular}{l|c}
\hline Geographical Area & Physicians per Capita \\
\hline United States & 2.5 \\
Massachusetts & 3.8 \\
\hline Other New England States & \\
\hline Connectiout & 3.4 \\
Maine & 2.2 \\
New Hampshire & 2.4 \\
Rhode Island & 2.9 \\
Vermont & 3.0 \\
High Technology States & \\
\hline California & 2.8 \\
Maryland & 3.8 \\
North Carolina & 0.9 \\
Texas & 2.0 \\
Washington & 2.6 \\
Large Industrial States & \\
Florida & 2.6 \\
Illinois & 2.5 \\
Michigan & 2.1 \\
New Jersey & 2.8 \\
New York & 3.6 \\
Ohio & 2.3 \\
Pennsylvania & 2.8 \\
\hline
\end{tabular}

Source: Physician data - AMA, Physician Characteristics and Distributions in the United States. 1993. Population data - World Almanac and Book of Facts, 1993.

c Non-federal status is defined as not under full-time employment by the federal government, induding the Army, Navy, Air Forœ, Veteran's Administration, the Public Health Senviœ, and other federally funded agencies. 

Table 5: Hospital Beds ${ }^{d}$ per 1000 Population - United States, Massachusetts, and Leading Competitor States

\begin{tabular}{l|c}
\hline Geographical Area & Hospital Beds per Capita \\
\hline United States & 3.7 \\
\hline Massachusetts & 3.6 \\
\hline Other New England States & \\
\hline Connecticut & 2.9 \\
Maine & 3.7 \\
New Hampshire & 3.1 \\
Rhode Island & 3.1 \\
Vermont & 3.2 \\
High Technology States & \\
\hline Califomia & 2.7 \\
Maryland & 2.8 \\
North Carolina & 3.3 \\
Texas & 3.5 \\
Washington & 2.5 \\
Large Industrial States & \\
\hline Florida & 3.9 \\
Illinois & 4.0 \\
Michigan & 3.5 \\
New Jersey & 3.8 \\
New York & 4.2 \\
Ohio & 4.0 \\
Pennsylvania & 4.3 \\
\hline
\end{tabular}

Source: Hospital bed data - AHA Hospital Statistics, 1992. Population data - World Almanac and Book of Facts, 1993.

Includes all non-federal short-term general and other specific hospitals, whose facilities and services are available to the public 

The percentage of physicians in generalist (primary care) practice in Massachusetts is on par with the national average. Table 6 shows that 31 percent of Massachusetts physicians are in general practice compared with 32 percent nationally. Thus, while Massachusetts remains substantially below the national objective of 50 percent generalist and 50 percent specialist physicians, the Commonwealth's standing is not unique and, as such, probably does not account for our spending differential.

Health Care Delivery Patterns. The style of care and utilization patterns in Massachusetts may be among the most important contributors to our relatively high health care expenditures. Table 7 shows that Massachusetts ranks among the top in the nation in terms of hospital care use. Among its competitor states, only New Jersey, New York and Pennsylvania have more inpatient days per capita than Massachusetts. Available data suggest that Massachusetts high inpatient-day use is attributable to a greater number of admissions per capita, not to longer hospital stays. The high admission rates are somewhat perplexing given the state's relatively large managed care penetration. Empirical research consistently shows approximately onethird fewer inpatient admissions among $\mathrm{HMO}$ enrollees. ${ }^{4,5}$ Massachusetts ranks first in the country in the portion of its population with HMO coverage. Task force members suggest that the findings may reflect the presence of managed care organizations in the Massachusetts market whose style is more reflective of traditional indemnity insurers than of HMOs. They suggest that the current erosion of these plans from the market may bring Massachusetts' inpatient care rates more in line with states whose managed care penetration is comparable to ours (e.g., California, Oregon, Avizona).

The high costs of care in Massachusetts may be partly attributable to the concentration of inpatient care that occurs in urban medical centers and teaching hospitals. While Massachusetts teaching hospitals are a vital resource, contributing to the state's prestigious reputation for high quality, technically sophisticated care, care in teaching settings is known to be more costly. More than half of inpatient days in New England (54.5 percent) occur in teaching hospitals compared with 42.6 percent nationwide. And more than half of New England's inpatient beds are in teaching hospitals (51.4 percent) compared with 37.7 percent nationally. ${ }^{6}$ While comparable state level data are unavailable, more than one-third of Massachusetts hospitals $(\mathrm{N}=55)$ have an affiliation with a medical school, 52 hospitals have a residency program approved by the American Council on Graduate Medical Education, and 19 hospitals are classified as academic medical centers. Accordingly, table 8 indicates that the average hospital admission in Massachusetts costs 13.6 percent more than the U.S. average. Among our competitor states, only New York, Connecticut and California had higher average costs per hospital admission than Massachusetts.

Personal Income. An additional factor that the literature considers in evaluating state variations in health care spending is personal income. At $\$ 23,811$, Massachusetts average per capita income is the fourth highest in the nation. Only Connecticurt, New Jersey and New York (each a competitor state of MA) have higher per capita personal 

Table 6: Non-Federal* Physiclan Distribution by Specialty Area - United States, Massachusetts, and Leading Competitor States

\begin{tabular}{|c|c|c|c|c|c|}
\hline \multirow{2}{*}{ Geographical Area } & \multicolumn{4}{|c|}{ Major Professional Activity: Patient Care } & \multirow{2}{*}{$\begin{array}{l}\text { Major Professional Activity: } \\
\text { Teaching, Administration, or } \\
\text { Research }\end{array}$} \\
\hline & $\begin{array}{l}\text { Generalist } \\
\text { Physicians }^{1}\end{array}$ & $\begin{array}{r}\text { Medical } \\
\text { Specialists }^{2}\end{array}$ & $\begin{array}{r}\text { Surgical } \\
\text { Specialists }^{3}\end{array}$ & $\begin{array}{r}\text { Other } \\
\text { Speclalists }^{4}\end{array}$ & \\
\hline United States & $32.5 \%$ & $5.9 \%$ & $21.2 \%$ & $22.8 \%$ & $6.1 \%$ \\
\hline Massachusetts & $30.9 \%$ & $5.9 \%$ & $18.1 \%$ & $24.2 \%$ & $9.7 \%$ \\
\hline \multicolumn{6}{|c|}{ Other New England States } \\
\hline Connectiaut & $30.8 \%$ & $6.3 \%$ & $20.2 \%$ & $23.8 \%$ & $8.4 \%$ \\
\hline Maine & $33.6 \%$ & $4.7 \%$ & $20.2 \%$ & $20.4 \%$ & $3.7 \%$ \\
\hline New Hampshire & $31.2 \%$ & $5.6 \%$ & $21.0 \%$ & $23.5 \%$ & $5.0 \%$ \\
\hline Rhode Island & $34.6 \%$ & $6.8 \%$ & $20.4 \%$ & $19.9 \%$ & $7.2 \%$ \\
\hline Vermont & $33.7 \%$ & $3.4 \%$ & $19.8 \%$ & $21.4 \%$ & $7.3 \%$ \\
\hline \multicolumn{6}{|c|}{ High Technology States } \\
\hline Califomia & $30.9 \%$ & $6.1 \%$ & $20.3 \%$ & $23.0 \%$ & $6.0 \%$ \\
\hline Maryland & $30.6 \%$ & $5.6 \%$ & $19.4 \%$ & $23.4 \%$ & $11.2 \%$ \\
\hline North Carolina & $32.1 \%$ & $5.6 \%$ & $22.5 \%$ & $22.1 \%$ & $6.7 \%$ \\
\hline Texas & $31.9 \%$ & $6.1 \%$ & $23.5 \%$ & $23.6 \%$ & $5.3 \%$ \\
\hline Washington & $33.2 \%$ & $5.0 \%$ & $19.2 \%$ & $22.9 \%$ & $5.7 \%$ \\
\hline \multicolumn{6}{|c|}{ Large Industrial States } \\
\hline Florida & $28.2 \%$ & $7.5 \%$ & $21.1 \%$ & $20.2 \%$ & $3.9 \%$ \\
\hline Illinois & $35.4 \%$ & $5.6 \%$ & $20.4 \%$ & $22.8 \%$ & $6.1 \%$ \\
\hline Michigan & $32.2 \%$ & $5.6 \%$ & $22.2 \%$ & $23.9 \%$ & $6.0 \%$ \\
\hline New Jersey & $33.9 \%$ & $7.2 \%$ & $21.1 \%$ & $21.4 \%$ & $5.9 \%$ \\
\hline New York & $33.2 \%$ & $6.1 \%$ & $19.8 \%$ & $22.9 \%$ & $7.7 \%$ \\
\hline Ohio & $32.9 \%$ & $5.6 \%$ & $22.2 \%$ & $23.4 \%$ & $5.4 \%$ \\
\hline Pennsylvania & $31.6 \%$ & $6.3 \%$ & $20.5 \%$ & $24.5 \%$ & $6.7 \%$ \\
\hline
\end{tabular}

* Non-federal status is defined as not under fulltime employment by the federal government

1 = includes physicians certified in family practice, general intemal medicine, and general pediatrics; $2=$ includes physicians specializing in allergy, cardiovoscular diseases, dembtology, gastroenterology, pediatric allergy, pediatric cardiology, and pulmonary diseases; $3=$ includes physicians specializing in colon and rectal surgery, general surgery, neurological surgery, obstetrics and gynecology, ophthalmology, orthopedic surgery, otolaryngology, plastic surgery, thoracic surgery, and urological surgery, and $4=$ includes physicians specializing in aerospace medicine, anesthesiology, child psychiatry, diagnostic radiology, emergency medicine, forensic pathology, general preventive medicine,

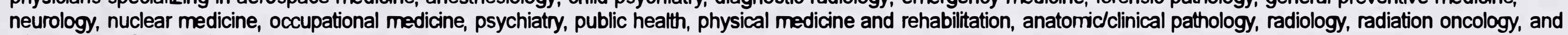
other unspecified specialties.

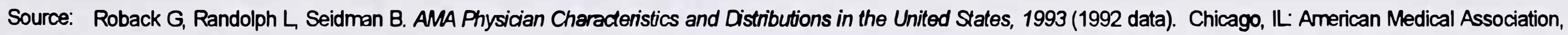
1993.

e Non-federal status is defined as not under full-time employment by the federal govemment, including the Army, Navy, Air Fonce, Veteran's Administration, the Public Health Service, and other federally funded agencies. 

Table 7: Annual Inpatient Days' per 100 Population - United States, Massachusetts, and Leading Competitor States

\begin{tabular}{l|c}
\hline Geographical Area & Inpatient Days per Capita \\
\hline United States & 89.61 \\
\hline Massachusetts & 95.93 \\
\hline Other New England States & \\
\hline Connectiaut & 79.93 \\
Maine & 94.64 \\
New Hampstire & 73.21 \\
Rhode Island & 88.93 \\
Vermont & 79.47 \\
High Tectnology States & \\
\hline Califomia & 61.76 \\
Maryland & 76.65 \\
North Carolina & 87.80 \\
Texas & 71.51 \\
Washington & 56.56 \\
Large Industrial States & \\
\hline Florida & 87.85 \\
Illinois & 95.53 \\
Michigan & 84.61 \\
New Jersey & 110.56 \\
New York & 129.47 \\
Ohio & 90.57 \\
Pennsylvania & 114.87 \\
\hline
\end{tabular}

Source: Hospital bed data - AHA Hospital Statistics, 1992. Population data - World Almanac and Book of Facts, 1993.

' Includes all non-federal short-term general and other specific hospitals, whose facilities and services are available to the public 

Table 8: Average Cost per Hospital* Admission, 1991- United States, Massachusetts, and Competitor States

\begin{tabular}{l|c}
\hline Geographical Area & Average Cost per Admission \\
\hline United States & $\$ 5,359.56$ \\
\hline Massachusetts & $\$ 6,086.45$ \\
\hline Other New England States & \\
\hline Connectiaut & $\$ 6,696.46$ \\
Maine & $\$ 4,866.67$ \\
New Hampshire & $\$ 4,995.27$ \\
Rhode Island & $\$ 5,063.24$ \\
Vermont & $\$ 4,672.93$ \\
High Technology States & \\
Califomia & $\$ 6,169.13$ \\
Maryland & $\$ 4,835.16$ \\
North Carolina & $\$ 4,759.15$ \\
Texas & $\$ 5,178.84$ \\
Washington & $\$ 5,035.31$ \\
Laroe Industrial States & \\
\hline Forida & $\$ 5,830.83$ \\
Illinois & $\$ 5,570.07$ \\
Michigan & $\$ 5,750.48$ \\
New Jersey & $\$ 5,136.29$ \\
New York & $\$ 6,823.06$ \\
Ohio & $\$ 5,132.51$ \\
Pennsylvania & $\$ 5,490.10$ \\
\hline
\end{tabular}

U.S. AHA-Registered community hospitals (all non-federal short-term general and other specific hospitals, whose facilities and services are available to the public)

Source: $\quad$ American Hospital Association. 1992 AHA Hospital Statistics (data compiled from the 1991 Annual Survey of Hospitals). Chicago, IL' American Hospital Association. 

incomes (table 9). The GAO identifies high personal income as a key factor in Massachusetts relatively high health care expenditures. ${ }^{4}$

High personal income is believed associated with higher health care spending for several reasons. First, more generous health coverage is typically associated with higher paying jobs. The availability of health coverage encourages use and the richer benefit packages available through higher paying jobs may provide coverage for more and different types of services. In addition, those with a higher personal income are better positioned to incur out-of-pocket health expenditures in using care and/or obtaining senices not covered by their insurance.

Finally, to the extent that higher personal incomes reflect generally higher wage rates, these will raise the cost of health care by increasing personnel costs in the health care sector. ${ }^{3}$ Table 10 indicates that health care sector wages in Massachusetts are 6 percent above the national average. Among its competitor states, only Connecticut, California, Florida and New Jersey have higher health sector wages.

Rich Benefit Packages. As indicated above, more generous health care coverage is presumed associated with higher health care expenditures, as individuals are able to obtain a wider array and greater number of covered senvices.

State-level data companing health care benefit packages does not exist for the overall insurance market. In addition, benefit information is entirely unavailable for employees whose benefits are provided by self-insured companies. An estimated 60 percent of medium and large-sized firms in New England self-insure. ${ }^{7}$ The federal Employee Retirement Income Security Act (ERISA) exempts these companies from state benefit requirements.

Data comparing HMO benefits by state offer the only available insights into the relative breadth and generosity of Massachusetts' health care benefits. These data indicate that New England HMOs offer a slightly richer benefit package than HMOs nationwide. New England HMOs are less likely to impose cost sharing requirements for hospital utilization and more likely to cover inpatient acute therapy (physical, occupational and speech). ${ }^{8} \quad$ Table 11 lists average monthly premiums for HMO family coverage in Massachusetts and its competitor states. The average premium in Massachusetts is $\$ 431$. This rate is twenty-two percent higher than the national average and higher than any of the Commonwealth's competitors except Maine and Connecticut.

Unfortunately, one cannot determine the extent to which higher premium costs reflect richer benefit packages versus higher expected health care expenditures (i.e., due to the myriad factors described above). 

Table 9: Personal Income Per Capita, 1992 - United States, Massachusetts, and Leading Competitor States

\begin{tabular}{l|c}
\hline Geographical Area & Personal Incorre Per Capita \\
\hline United States & $\$ 20,114$ \\
\hline Massachusetts & $\$ 23,811$ \\
\hline Other New England States & \\
\hline Connectiout & $\$ 27,123$ \\
Maine & $\$ 18,100$ \\
New Hampshire & $\$ 22,596$ \\
Rhode Island & $\$ 19,895$ \\
Vermont & $\$ 18,834$ \\
High Technology States & \\
\hline Califomia & $\$ 21,472$ \\
Maryland & $\$ 23,249$ \\
North Carolina & $\$ 17,986$ \\
Texas & $\$ 18,333$ \\
Washington & $\$ 21,088$ \\
Large Industrial States & \\
\hline Forida & $\$ 19,494$ \\
Illinois & $\$ 21,980$ \\
Michigan & $\$ 19,680$ \\
New Jersey & $\$ 26,969$ \\
New York & $\$ 23,842$ \\
Ohio & $\$ 18,860$ \\
Pennsylvania & \\
\hline
\end{tabular}

Source: U.S Bureau of Economic Analysis, Survey of Current Business, July 1993. 

Table 10: Wage and Salary Index ${ }^{9}$ among Health Care Delivery Employees, 1991 United States, Massachusetts, and Leading Competitor States

\begin{tabular}{l|c}
\hline Geographical Area & Relative Pay per Employee \\
\hline United States & 1.00 \\
\hline Massschusetts & 1.06 \\
\hline Other New England States & \\
\hline Cornecticut & 1.16 \\
Maine & 0.85 \\
New Hampshire & 0.95 \\
Rhode Island & 0.96 \\
Vermont & 0.81 \\
High Tectnology States & \\
\hline California & 1.16 \\
Maryland & 1.04 \\
North Carolina & 0.98 \\
Texas & 0.93 \\
Washington & 0.93 \\
Large Industrial States & \\
Florida & 1.07 \\
Illinois & 0.99 \\
Michigan & 0.99 \\
New Jersey & 1.09 \\
New York & 1.04 \\
Ohio & 0.97 \\
Pennsylvania & 1.02 \\
\hline
\end{tabular}

Sourc:

U.S. Department of Commerce, Bureau of Economic Analysis. Wage and Salary Disbursement by Industry (data complied from the Survey of Current Business). Washington, DC: Bureau of Economic Analysis, 1992.

9 Wage and salary index is based on U.S. average $=1.0$. A state index greater than 1 indicates wages and salaries exceed the U.S. average. A state index value less than 1 indicates average wages and salaries lower than the U.S. average. 

Table 11: Average Monthly Family Premiums, HMOs', 1992 - United States, Massachusetts, and Leading Competitor States

\begin{tabular}{|c|c|}
\hline Geographical Area & Average Family Premiums \\
\hline United States & $\$ 353.57$ \\
\hline Massactusetts & $\$ 431.17$ \\
\hline \multicolumn{2}{|c|}{ Other New England States } \\
\hline Cornectiout & $\$ 474.13$ \\
\hline Maine & $\$ 468.38$ \\
\hline New Hampshire & $\$ 429.19$ \\
\hline Rhode Island & $\$ 311.49$ \\
\hline Vermont & $\$ 352.04$ \\
\hline \multicolumn{2}{|c|}{ High Technology States } \\
\hline California & $\$ 362.43$ \\
\hline Mayland & $\$ 368.41$ \\
\hline North Carolina & $\$ 373.55$ \\
\hline Texas & $\$ 351.99$ \\
\hline Washington & $\$ 359.15$ \\
\hline \multicolumn{2}{|l|}{ Large Industrial States } \\
\hline Forida & $\$ 295.63$ \\
\hline Illinois & $\$ 335.02$ \\
\hline Michigan & $\$ 350.40$ \\
\hline New Jersey & $\$ 413.65$ \\
\hline New York & $\$ 325.86$ \\
\hline Ohio & $\$ 336.24$ \\
\hline Pennsylvania & $\$ 321.65$ \\
\hline
\end{tabular}

Source: $\quad$ Marion Merrill Dow, Managed Care Digest, 1993

${ }^{n}$ Indudes group and staff-model HMOs, IPAs, and network HMOs. Non-Medicare premiums only. 

Section Summary. Of the factors examined, Massachusetts' high relative health care expenditures appear to be primarily attributable to (1) high personal income,

(2) a large health care delivery infrastructure and (3) utilization patterns that feature more frequent inpatient care, a large portion of which is delivered in urban medical centers.

Each of these factors represents a double edged sword with respect to the Commonwealth's economy overall. Our relatively high personal income, while contributing to high spending and high health care costs, also reflects the predominance of a highly skilled, well educated labor force. The large health care infrastructure represents a source of employment for more than 10 percent of Massachusetts workers. And while the utilization pattems associated with large urban teaching facilities raise the cost of medical care, they also make available to Massachusetts residents care that is nationally and intemationally renowned for its quality and innovation.

In addition, as Massachusetts considers the extent to which overt measures are required to bring health care expenditures in line with competitor states, we must consider the importance of health expenditure growth along with gross levels of spending. A survey of Massachusetts businesses, conducted by a working group of this task force, indicates that gross spending and rates of growth are of comparable concem to Massachusetts employers. Business leaders suggest that attaining predictable rates of increase in health care costs, at or below the rate of inflation, must be a priority. Toward that end, Massachusetts experience is more favorable than its competitors. (See page 26 of this report, "Cost Control in the Health Care Sector").

\section{INSURING THE UNINSURED}

An estimated 664,000 Massachusetts residents lack health insurance. This represents 11 percent of the total population and 13.2 percent of the non-elderly (age <65) population. Elderly persons (except non-U.S. citizens) received federal Medicare insurance.

These estimates of the number of uninsured derive from national survey data (Current Population Survey) obtained in March 1992. ${ }^{9}$ The most recent detailed profile of Massachusetts uninsured derive from a 1989 survey cormmissioned by the Massachusetts Department of Medical Security (DMS). At that time, there were an estimated 455,000 uninsured residents in the Commonwealth. The DMS findings were consistent with then-current estimates from the Current Population Survey (CPS). For purposes of this report, we base the estimated number of uninsured on the most recent data available from the CPS $(\mathrm{N}=664,000)$ but apply distribution profile information (e.g., employment status, income, demographics) from the DMS report. ${ }^{10}$ 

Estimated Cost of Providing Coverage to the Uninsured. There is no single, agreed upon methodology by which to project the cost of insuring the uninsured. However, a critical methodologic requirement is that projected costs reflect net not gross costs. That is, not all of the services and products to be used by the "newly insured" will be new. One must account for care currently provided to uninsured residents in doctors offices, community health centers, acute medical centers as well as pharmaceutical, vision and other products currently provided. Some of these services are reimbursed through the state uncompensated care pool and other means, but many are not. Any estimate of covering the uninsured must adjust for the value of health services and products currently provided.

Following, we apply two different methodologies to estimate the net cost of covering the uninsured. Both methodologies assume that there are currently 664,000 uninsured in Massachusetts and that all would receive coverage under reform. Both methodologies find a net cost between $\$ 500$ million and $\$ 600$ million. The distribution of these costs (government, employers, individuals) will depend largely on the mechanisms used to attain universal coverage. The extent to which costs would increase, persist or decline overtime will depend on myriad factors induding overall health care cost containment, utilization trends and realization of out-year savings through universal coverage.

Projected Utilization. One methodology used in projecting net costs of caring for the "newly insured" estimates the difference between current and projected utilization. The Congressional Budget Office (CBO) estimates that the uninsured presently use approximately 64 percent of the services used by insured individuals. This estimate adjusts for demographic and health status characteristics. ${ }^{2}$

Using the CBO methodology and assumptions, the Urban Institute has provided estimates of expected utilization to this task force. The Uiban Institute model was originally constructed to assist the Clinton administration task force, so the model presumes the imposition of an employer mandate as specified in the Clinton proposal. The information provided remains instructive, despite uncertainty regarding the ultimate formulation of national health care reform.

The Urban Institute methodology estimates that the value of services and products currently provided annually to an uninsured adult and child are $\$ 1372$ and $\$ 783$, respectively. Under the Clinton reform proposal, the estimated utilization is project to be as follows:

Employed adult $\$ 2395$

Child of employed adult $\$ 1367$

Unemployed adult $\$ 1610$

Child of unemployed adult 

Based on these estimates and the employment distribution of Massachusetts uninsured, the new utilization costs among the "newly insured" would be $\$ 546,260,184$. This estimate presumes that there are 664,000 Massachusetts residents currently uninsured and that all would have insurance following reform. The nature of coverage would differ for employed and unemployed.

Projected Cost. An altemative methodology computes the new cost associated with covering the uninsured as the difference between projected health insurance premiums and the value of services and products currently provided to the uninsured.

We estimate the average monthly individual premium to be $\$ 144.19$. This premium represents the present average non-group (individual) premium." A nearly identical rate was assumed by the Massachusetts Association of HMOs (MAMMO) in its projections of covering the uninsured. MAHMO assumed that uninsured persons in all regions of the state could receive HMO coverage for a monthly premium of $\$ 141.95 .^{11}$

In accordance with these estimates, annual premiums for Massachusetts' uninsured would cost $\$ 1,148,905,920$. This estimate represents an upper bound in that it does not account for the likely availability of family premium rates. For families of 3 persons or more, a family premium is likely lower than multiple individual premiums applied across all family members.

From the total amount of premium dollars, we deduct $\$ 560$ million - the estimated value of health services and products currently provided to Massachusetts uninsured. ${ }^{12}$ The figure includes:

- Uncompensated care provided in acute hospitals

$\$ 480$ million

- Uncompensated care provided in free-standing community health centers $(\mathrm{N}=34)$

- Medical Security Program (coverage for unemployed uninsured)

* This premium for Blue Cross nongroup indemnity insurance ( $\$ 144.19 /$ month) provides a standard set of mandated indemnity benefits with a $\$ 2000$ deductible and a $20 \%$ co-payment for outpatient services received thereafter. The insurer cannot deny coverage based on pre-existing conditions, but may impose up to a 2-year waiting period for care related to these conditions. A nearly identical premium ( $\$ 141.95)$ buys individual coverage through an HMO which includes all state mandated benefits and all benefits required for federally qualified HMOs. The HMO coverage has no deductible, small visit co-payments (\$5 - \$10) and full coverage for preventive care. Individuals can be denied HMO enrollment based on a health screening examination, but if enrolled, cannot have waiting periods or pre-existing condition exclusions imposed. 

- Healthy Kids Program (coverage for uninsured children ages 1-6)

- Common Health Program (coverage for uninsured disabled)

- Center Care Program (community health center care for uninsured)

The figure represents a lower bound on the total value of senvices and products received by the uninsured. Data on several categories of senices and products are unavailable (e.g., free care received in doctors offices, pharmaceuticals, vision products, dental senvices).

Based on these figures, the net cost of covering the uninsured is estimated to be $\$ 588,905,920$.

Strategies for Attaining Universal Coverage. Strategies for attaining universal coverage fall generally into three categories: (1) employer mandate, (2) individual mandate, (3) single payer. The strategies differ in the locus of responsibility for obtaining health insurance and in the extent to which they achieve universal coverage. Each strategy has, associated with it, different political and administrative bamiers and different social costs. The following sections summarize the salient attributes of each strategy.

Employer Mandate. An employer mandate describes a strategy by which coverage is sought for working adults by requiring employers to make health insurance available and to pay a defined portion of the cost. Under some constructs, an employer mandate also requires that coverage be extended to those dependents of the employed who would otherwise remain uninsured. Employer mandates also differ in the extent to which they require firms to cover part-time and temporary workers and in the exemption of firms smaller than a designated cut-off. Thus employer mandate formulations differ in the extent to which they achieve universal coverage.

While Massachusetts companies vary widely in their support for (or opposition to) an employer mandate, business leaders stress that the Commonwealth should not undertake this strategy in isolation from federal policy. They emphasize that such a policy would greatly exacerbate the cost-disadvantage that Massachusetts' businesses already face in competing nationally and intemationally.

In Massachusetts, as in the U.S. overall, the vast majority of uninsured (84 percent) are employed or reside in a household in which at least one adult is employed. ${ }^{10}$ These data indicate that even an employer mandate of the strictest variety mandating coverage of all part-time, seasonal and temporary workers and their dependents - would leave 16 percent of the currently uninsured still uncovered $(\mathrm{N}=106,000)$. This estimate presumes no job displacement resulting from the 

imposition of an employer mandate."

Massachusetts Chapter 23 legislation provides a useful point of reference regarding the potential for achieving universal coverage under an employer mandate. Under the 1988 law, a minimum contribution toward health insurance was required of employers with more than six permanent employees working more than 20 hours per week. Coverage was to include those dependents of the employed who would otherwise be uninsured. The DMS report estimated that 42 percent of Massachusetts uninsured would obtain coverage through the employer mandate. In order to cover segments of the uninsured not covered by the employer mandate, Chapter 23 supplemented the employer mandate with other provisions. Table 12 indicates the portion of Massachusetts working unemployed by their company size. An estimated sixty percent of the working uninsured are employed by small businesses ( $<25$ employees). These data indicate the barriers to achieving universal coverage through a mandate that exempts small firms. Yet a policy (such as that prescribed in the Clinton proposal) that mandates employer participation regardless of firm size, is widely criticized by small businesses as unaffordable. Such a mandate would necessanily be accompanied by subsidies to small businesses. While the magnitude of employer subsidies has been estimated at the national level, state-level estimates are unavailable.

Small-Group Insurance Reform. Changes in the small group insurance market are often posited as a meaningful strategy through which to encourage and facilitate participation among small employers. The logic is that small employers are prevented from entering the market or forced to drop coverage because of high costs associated with small-group insurance.

Provisions in Massachusetts Chapter 495 made important changes in the small group insurance market. An important clause in Chapter 495 mandated guaranteed issue and renewal of coverage to small groups $(\leq 25)$, effective April 1, 1992. The law also attempted to reduce the variability in small group insurance rates by requining that carniers have no more than a two-fold difference in their small-group rate spectrum.

To date, Chapter 495 has been extremely effective for those small employers who already provide insurance coverage. It has prevented their coverage from being unduly terminated and has prevented large rate increases that might force employers to drop coverage. However, for those small companies not providing health insurance, the law has not been successful at encouraging entry into the market. ${ }^{12}$ This is presumed to be because the law has not affected significant reductions in the

-.. Estimates on the extent to which job loss will occur under an employer mandate are highly sensitive to the mandate formulation. To date, national estimates have ranged from 3.1 million jobs lost to 661,000 jobs created nationally. 



\section{Table 12: Percent of Employed Uninsured by Firm Size}

\begin{tabular}{l|c}
\hline Firm Size & Percent of employed uninsured \\
\hline$<6$ & 34 \\
$6-9$ & 14 \\
$10-24$ & 12 \\
$25-99$ & 14 \\
$100-200$ & 9 \\
$200+$ & 17 \\
Total & 100 \\
\hline
\end{tabular}

Source: Blendon et al., A Household Sunvey of the Health Insurance Status of Massachusetts Residents, 1990. 

cost of small-group insurance.

Individual Mandate. An individual mandate refers to a strategy for attaining universal coverage by mandating that all residents carry health insurance. The national health care reform proposal by Senator Chafee (R-RI) relies on an individual mandate as the mechanism through which to attain universal coverage. This is presently one of the three leading health care reform proposals under consideration in the Congress.

In addition, the Clinton administration proposal may be conceived as combining an individual and employer mandate in that individuals who lack employment-based coverage are required to purchase insurance individually (through a regional health insurance purchasing alliance).

There are two principal criticisms of an individual mandate strategy. The first is that it is administratively complicated and difficult to enforce. The second is that there are no estimates regarding the public cost required in the form of subsidies to low income individuals and families.

Administrative Complexity. While analogies have been drawn to requiring automobile insurance for vehide registration, the difficulties of enforcing an individual mandate policy are considerable. One mechanism that has been proposed would require proof of insurance to be submitted with annual tax forms. Another would require individuals to show proof of insurance upon employment and annually thereafter. Severe penalties for failing to carry insurance have been proposed as a means to ensure that individuals obtain and retain coverage. For example, health care providers might be permitted to require payment of back premiums and penalties from an individual who seeks care and lacks health insurance. The strategy remains untested with no indication of the degree to which compliance would be problematic.

Public Cost. Under most individual mandate formulations, it is presumed that employers would be permitted to continue providing health insurance as an employment benefit. To date, there have been no estimates regarding the extent to which employers would continue their contributions toward health insurance. This poses a critical barrier to estimating the public cost of an individual mandate policy.

Data from the 1989 DMS report on the uninsured permit some estimation. That report finds that 17.5 percent of Massachusetts uninsured $(\mathrm{N}=116,000)$ have income below poverty; 37.5 percent $(\mathrm{N}=249,000)$ have income between 100 and 199 percent of poverty. ${ }^{10}$

Poverty is defined as $\$ 6,950$ annually for a family of one and $\$ 14,350$ for a two-adult family of four. Table 13 estimates the percent of total annual income that would be consumed by health care premiums for individuals and families at varying levels of income. We presume monthly individual and family premiums of $\$ 144.19$ (described 

Table 13: Annual Health Care Premiums as a Percent of Annual Income by Poverty Level'

\begin{tabular}{|c|c|c|c|c|c|c|}
\hline \multirow[b]{2}{*}{$\begin{array}{l}\text { Percent } \\
\text { of } \\
\text { Poverty }\end{array}$} & \multicolumn{3}{|c|}{ Individual } & \multicolumn{3}{|c|}{ Two-Adult Family of Four } \\
\hline & $\begin{array}{l}\text { Annual Health } \\
\text { Care Premium } \\
\text { (unsubsidized) }\end{array}$ & $\begin{array}{l}\text { Annual } \\
\text { Income }\end{array}$ & $\begin{array}{c}\text { Health } \\
\text { premium as a } \\
\text { percent of } \\
\text { annual income }\end{array}$ & $\begin{array}{l}\text { Annual Health } \\
\text { Care Premium } \\
\text { (unsubsidized) }\end{array}$ & $\begin{array}{l}\text { Annual } \\
\text { Income }\end{array}$ & $\begin{array}{l}\text { Health premium } \\
\text { as a percent of } \\
\text { annual income }\end{array}$ \\
\hline 100 & $\$ 1,730$ & $\$ 6,950$ & 25.89 & $\$ 4,758$ & $\$ 14,350$ & 33.17 \\
\hline 200 & $\$ 1,730$ & $\$ 13,900$ & 12.45 & $\$ 4,758$ & $\$ 23,700$ & 20.08 \\
\hline 300 & $\$ 1,730$ & $\$ 20,850$ & 8.30 & $\$ 4,758$ & $\$ 43,050$ & 11.05 \\
\hline 400 & $\$ 1,730$ & $\$ 27,800$ & 6.22 & $\$ 4,758$ & $\$ 57,400$ & 8.29 \\
\hline
\end{tabular}

Health care premium figures based on monthly rate of $\$ 144.19$ for individuals and $\$ 396.52$ for families. 

above) and $\$ 396.52$, respectively.

For an individual with income up to $250 \%$ of poverty, the annual insurance premium would represent more than 10 percent of annual income. The same would be true for families with annual income up to 331 percent of poverty. This does not indude out of pocket expenses for care (e.g., visit co-payments, prescriptions). Thus, under an individual mandate, substantial subsidies would be required to make health insurance affordable to those well above federally-established poverty levels.

To estimate the magnitude of these subsidies, we simulated the cost of a theoretical subsidy program. Such a program might operate on a sliding scale, wherein health premiums would be fully subsidized for those with incomes at or below 100 percent of poverty, subsidized 90 percent for those with incomes between 101 and 200 percent of poverty, and subsidized on a sliding scale for those with incomes between 201 and 400 percent of poverty (e.g., premiums might be subsidized to cap private premium contributions at 5 percent of annual income).

Under this theoretical strategy, and assuming full continuation of present employer contributions toward insurance, the cost of an individual mandate would involve subsidizing premiums for the currently uninsured as follows:

Annual Income

Poverty or below

101 - 200 percent poverty

201 - 400 percent poverty

TOTAL
Subsidy

$\$ 200,712,480$

$\$ 387,755,748$

Data unavailable

$\$ 588,468,228$

Data on the uninsured population with incomes between 201 and 400 percent of poverty are unavailable. Thus, the above calculation underestimates total subsidy costs because subsidies to this group are excluded.

The results are extremely sensitive to the assumed continuation of effort among employers currently providing insurance. In the extreme, if employers entirely ceased health care premium contributions, a theoretical subsidy program as defined above

Family premium rates are estimated to be 2.75 -times individual rates.

The similarity between these subsidy estimates and the estimated net cost of covering the uninsured is purely coincidental. The premium subsidies described here represent gross outlays and do not take into account the net effect on public outlays as other programs for the uninsured are able to be curtailed. 

would cost $\$ 22.5$ billion.

This is based on current statewide income data that indicate 2.5 percent of Massachusetts residents have income below poverty and 21.2 percent have income between 100 and 200 percent of poverty. Again, the calculations exclude the cost of subsidizing premiums for those with incomes between 200 and 400 percent of poverty as data on this population are unavailable. Note, however, that under this scenario, significant shifts in the population income distribution would likely occur as employers increased wages to compensate for benefit reductions. This would also considerably increase the state tax base. The computations do not take into account these potential income shifts associated with employers' termination of health benefit contributions.

Nonetheless, these simulations of a state subsidy program make clear that, to the extent that an individual mandate changes social norms with respect to employerprovided health benefits, the public costs required to subsidize individual health care premiums may be considerable.

Single Payer. A single payer strategy for attaining universal coverage typically refers to a system in which there is a single public payer for health care senvices and products. It represents a decisive shift away from the current, employment-based system of health insurance to a system in which a single entity - usually the federal or state government - becomes the exclusive payer for health insurance.

A provision in the Clinton administration reform proposal allows states to adopt a single payer system as a means of achieving federally mandated requirements. Despite the inclusion of this provision, no state is currently planning adoption of a single payer system. The two other leading proposals in the Congressional health care reform debate (Cooper and Chafee), do not offer states the option of adopting a single payer system.

The primary bamier to adopting a single payer system is the magnitude of the transition that it represents in both the logistics and the ideology of health insurance. The current system of employment-based coverage is deeply entrenched in the social culture of this nation, dating back to the earliest days in which health insurance became available. The vast majority of Massachusetts employers - large and small offer health insurance as an employment benefit. Many of these businesses, particularly the larger ones, regard the provision of health insurance as an important and valued role. While they urgently seek attention to the unrestrained growth in health care costs that threatens their profitability and in some cases, viability, a large portion of employers would like to retain their role in negotiating and providing health benefits for their employees. 

Nonetheless, many of the failings of the current system have their roots in a health insurance system that is employment-based. Reliance on employment-based coverage, with no requirement for its provision, leaves a segment of the population without health insurance. Proponents of a single payer system highlight the guaranteed universality of coverage as one of this strategy's leading strengths.

A minority of members of this task force express interest in a single payer approach to attaining universal coverage. The majority of members favor an altemative strategy for achieving the unanimously accepted goal of universal coverage.

Because a single payer approach has received relatively little attention here or nationally, there are no cost estimates available.

\section{COST CONTROL IN THE HEALTH CARE SECTOR}

Controlling the growth of health care costs is a leading goal of national and state health system reform. Nationally, health care costs continue to grow at a rate nearly double that of general inflation. In Massachusetts, despite gross expenditures that are well above national norms, the rates of growth have been somewhat more encouraging. Table 14 indicates that between 1980 and 1991, Massachusetts annualgrowth in health expenditures averaged 10.3 percent - a rate just below the national average and well below the rates among many of the Commonwealth's leading competitors.

And recently, rates of health premium growth in Massachusetts appear to be approaching the general inflation rate. In 1994, Massachusetts leading HMOs' premiums increased by an average of 5 percent (relative to 1993 rates for equivalent benefits). Indemnity plan increases averaged 13 percent, the lowest rate of increase in 8 years.

A critical question that remains to be addressed at the state and national levels is the extent to which market versus regulatory forces should be employed to restrain health care costs. The three leading national reform proposals presently being debated in the Congress each emphasize market competition as a means to bring health care costs under control. The plans differ in the extent to which they supplement market pressures with regulatory cost control mechanisms. The working group on Massachusetts' businesses from this task force notes widespread business support for a model such as managed competition which integrates competitive and regulatory solutions to health care system problems. ${ }^{13}$ The discussion that follows describes the leading competitive and regulatory cost control strategies and documents what is known about each. 

Table 14: Average Annual Growth in Expenditures for Health Services', 1980-1991 United States, Massachusetts, and Leading Competitor States

\begin{tabular}{l|c}
\hline Geographical Area & Annual Growth in Expenditures \\
\hline United States & 10.5 \\
\hline Massachusetts & 10.3 \\
\hline Other New England States & \\
\hline Cornectiaut & 11.1 \\
Maine & 10.6 \\
New Hampshire & 13.4 \\
Rhode Island & 9.7 \\
Vermont & 11.2 \\
High Tectinology States & \\
\hline California & 10.3 \\
Maryland & 10.6 \\
North Carolina & 12.0 \\
Texas & 11.2 \\
Washington & 11.7 \\
Large Industrial States & \\
\hline Forida & 12.5 \\
Illinois & 8.2 \\
Michigan & 8.6 \\
New Jersey & 11.3 \\
New York & 10.1 \\
Ohio & 9.4 \\
Pennsylvania & 10.3 \\
\hline
\end{tabular}

Adapted from: Levit, Lasenby, Cowan, and Letsch, Health Affairs 1993;12(3):12-13.

1 Health service expenditures indude expenditures for hospital care, physician senvices and prescription duggs purchased in retail outlets. 

Cost Control Through Market Competition. Recent gains in restraining the growth of health care costs are believed attributable to a combination of employer pressure and anticipation of national health care reform. The relative contribution of each is impossible to determine. However, task force members believe that the runaway health care premium inflation in the 1980s was due, at least in part, to employers' relaxed attitude toward health care costs during those economically profitable years. With larger profit margins, there was less urgency and attention given to the magnitude and growth of health care premium costs.

Task force members are united in their feeling that the 1990s have marked a decisive tuming point with respect to health care costs. They maintain that the experience of the 1980s will not likely recur as employers will continue firm negotiation with insurers, vigilant to prevent rates of premium inflation like those of the previous decade. This commitment, along with the recent success at restraining health insurance premium increases, indicates that market pressures may go a long way toward restraining the grouth in health care costs.

Health insurance (plan) purchasing cooperatives have been proposed as one tool to enhance employers' capacity to hamess market forces and achieve health care cost control. Despite vast recent public attention, their potential for achieving increased market competition and containing health care costs remains uncertain. The discussion below highlights the original and current conception of purchasing cooperatives and the role that they might play in a reformed health care system.

Health Plan Purchasing Cooperatives. Each of the leading national health care reform strategies - and several of the plans recently adopted by states nationwide - rely on a strategy of "managed competition" as a means to contain health care costs.

Managed competition was originally conceived and described by Stanford University economist Alain Enthoven. ${ }^{14}$ Since that time, Enthoven has worked in collaboration with physician Paul Ellwood and a team of colleagues known as the Jackson Hole Group.

A structural element that is fundamental to managed competition, as proposed by the Jackson Hole Group, is the health plan purchasing cooperative (HPPC) or health alliance. The HPPC is a vehicle through which to allow individuals and groups to pool risk, achieve economies of scale in purchasing, and enhance competition by providing information to consumers. The Jackson Hole Group recently prepared a manual to advise Govemors on those features of a HPPC that the group sees as central to a managed competition strategy. ${ }^{15}$

National and state health care reform plans based on the managed competition approach have in common their integration of the HPPC. However, the nature of the HPPC differs greatly across plans. Among the leading points of difference are: 

(1) whether purchase of insurance through the HPPC is voluntary or mandatory;

(2) the size of employers who must (or may) purchase insurance through the HPPC;

(3) whether HPPCs in a region are exclusive or competing;

(4) the govemance structure of the HPPC;

(5) whether the HPPC negotiates prices with insurers or offers all certified plans.

Each of these differences holds important implications with respect to the scope and feasibility of implementing managed competition.

Employer Participation Requirements. The Clinton health care reform proposal employs managed competition in the context of an employer mandate. Employers with fewer than 5,000 employees must buy insurance through a common regional HPPC. States are permitted to define multiple regional HPPCs. Employers with 5,000 or more employees may purchase insurance separately or through the regional alliance. A large employer purchasing insurance separately is termed a corporate alliance under the Clinton plan. The plan imposes a corporate tax to dissuade large employers from opting out of the regional alliance.

The size requirements for businesses participating in a HPPC remain a source of tremendous disagreement nationally and locally. The Jackson Hole Group has emphasized that HPPCs were conceived as a purchasing vehicle for small employers and individuals. The group envisioned that large employers would continue to act as their own sponsors. The rationale for pooling small groups and individuals was the historic difficulty these parties experienced in obtaining and retaining coverage. ${ }^{15}$

- Small groups are too small to spread the risk of high medical costs. This leaves them subject to medical undenwriting and drastic rate inflation or coverage termination if one or more group members experience severe illness.

- Small groups cannot achieve economies of scale in purchasing and administering health insurance. Small employers typically lack the expertise needed to evaluate differing plans.

- Small employers are typically forced to offer a single choice of plan to individuals as carriers will not split the group.

In Massachusetts, the business community also expresses concem regarding the required HPPC participation of companies with fewer than 5,000 employees. As indicated above, many employers view negotiation and selection of health benefits as a valued and critical role. Many would prefer to retain that function without being forced to participate in a HPPC. 

Both the Cooper and Chafee health care reform proposals suggest that HPPC participation be limited to companies of 100 employees or less. Both proposals make HPPC participation voluntary. Note that without reform or repeal of the federal Employee Retirement and Income Security Act (ERISA), state law cannot require HPPC participation.

Given the intensity of the current debate over this issue, it is valuable to note the small percentage of employers who would be affected by a cutoff of 100 versus 5,000 for HPPC participation. Table 15 indicates that 178 Massachusetts businesses (2.6 percent) have between 100 and 5000 employees. Likewise, only 2.2 percent of companies nationally are in this range. ${ }^{16}$ Data on the distribution of employees by firm size indicate that approximately one-third of Massachusetts' workforce is employed in businesses of this size. One-half of Massachusetts' workers work for firms with fewer than 100 employees. $^{16}$

The appropriate number of purchasing alliances for Massachusetts will depend, in part, on the expected scope of employer participation statewide. The Jackson Hole Group recommends that a HPPC represent at least 300,000 individuals and between 30 and 50 percent of the entire market. ${ }^{15}$

An additional factor that must be weighed in considering the appropriate number of regional alliances is the feasibility and political costs associated with defining multiple alliance boundaries. Task force members note that this would be a highly contentious, highly politicized undertaking as suburban and rural areas struggled to avoid alliance borders linking their communities with urban areas and the associated costs of caring for higher risk populations.

Massachusetts Experience with Small Group Purchasing Cooperatives. There are two organizations that presently act as purchasing sponsors for a large number of small businesses in Massachusetts. The organizations bear some (though not complete) likeness to health plan purchasing cooperatives, as envisioned by the Jackson Hole Group. Like the Jackson Hole HPPC, these organizations perform administrative and informational functions. They do not negotiate prices with the insurance plans.

The Small Business Service Bureau, Inc. and MBA Companies both act as purchasing agents for Massachusetts companies with fewer than 10 employees. Both organizations have operated here since the early 1960's. Each currently serves approximately 5,000 small Massachusetts businesses.

Under Chapter 495, small group premium rates are fixed by carriers and cannot be experience rated. Thus, there is no premium negotiation role for small groups or their purchasing agents. 

Table 15: Establishment ${ }^{k}$ Size in Massachusetts and the United States, 1991

\begin{tabular}{l|rc|cc}
\hline \multirow{2}{*}{\begin{tabular}{l} 
Establishment \\
\cline { 2 - 5 } Size
\end{tabular}} & \multicolumn{3}{|c}{ Massachusetts } & \multicolumn{2}{|c}{ United States } \\
\cline { 2 - 5 } & $\mathrm{N}$ & $(\%)$ & $\mathrm{N}$ & $(\%)$ \\
\hline $1-99$ & 149,859 & $(97.35 \%)$ & $6,066,447$ & $(97.84 \%)$ \\
$100-4999$ & 178 & $(2.64 \%)$ & 133,892 & $(2.15 \%)$ \\
$5000+$ & 15 & $(0.01 \%)$ & 311 & $(0.01 \%)$ \\
& 153,939 & $(100 \%)$ & $6,200,650$ & $(100 \%)$ \\
\hline TOTAL & & & & \\
\hline
\end{tabular}

Source: U.S. Department of Commerce, Bureau of the Census, County Business Pattems.1991. In press: January 1994.

k The U.S. Department of Commerce distinguishes 'establishment' from 'company'. An establishment may be a stand-alone company or may constitute a single location of a multisite company. State-level data on company size are unavailable due to complications posed by multistate companies. 

Both organizations note that small group insurance reform in Massachusetts (Chapter 495 ) has been effective at protecting small groups from undue termination of benefits and from drastic rate increases that might force voluntary termination. Under Chapter 495 , small groups are guaranteed issue and renewal of coverage. In addition, carriers cannot vary premium rates by more than two-fold over their entire small group ( $\leq 25$ subscribers) market. The organizations note that small group reforms have not significantly increased the number of small groups seeking coverage as premium rates have not been substantially reduced.

Essential Features of the Purchasing Cooperative. There are two functions that are virtually universally agreed upon as essential to a managed competition strategy and within the domain of the HPPC. These are: (1) applying a risk adjustment formula to health plan premiums and (2) obtaining and disseminating information on health plans to consumers.

Premium Rjsk Adjustment. An essential feature of managed competition is the adjustment of premium payments that health plans receive so as to reflect the risk of their enrolled population. It is widely recognized that without risk adjustment, health plans that receive a capitated (fixed) payment per enrollee have an incentive to engage in risk selection (i.e., enroll only the healthiest available subscribers). In the absence of risk adjustment, (1) individuals who are old, sick or othenvise expected to require substantial medical care will have difficulty obtaining coverage and (2) those capitated plans that serve a disproportionate share of severely ill patients may experience financial losses.

Risk adjustment is envisioned as a function to be performed by the HPPC. A widely accepted strategy presumes that premiums offered to and paid by individuals and employers would be community rated. Upon distributing premiums to each health plan, the HPPC would adjust the sum allocated to reflect the risk (i.e. expected utilization) in the plan's membership.

If national health care reform legislation based on a managed competition strategy passes the Congress, the formula for risk adjustment will likely be federally defined. Altematively, individual states adopting managed competition will need to devise an appropriate risk adjustment formula.

Three potential categories of risk adjusters have been described. ${ }^{17}$ These include (1) patient sociodemographic characteristics, (2) patient health status and (3) patient prior health care utilization. While possibly the best predictor of utilization, the latter category is generally exduded from consideration as a risk adjuster because of the perverse incentives it creates with respect to cost control.

Figure 1 illustrates the extent to which these groups of adjusters have been shown to predict utilization at the individual patient level. Note that no set of adjusters perfectly 



\section{Figure 1}

\section{Predicting Health Care Use with Capitation Rate Adjusters}

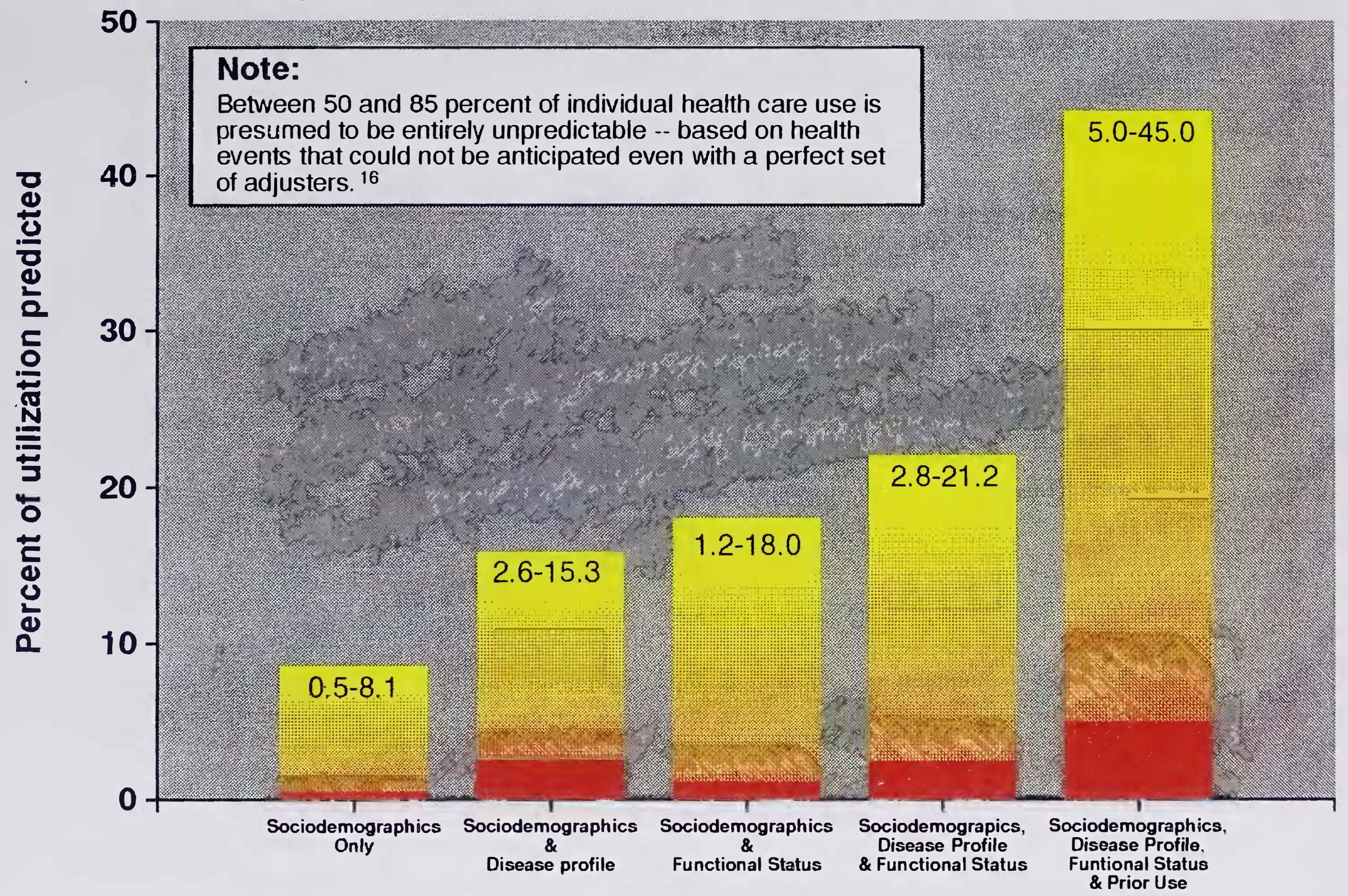

Ranges reflect differences in predictive potential that depend upon (1) the chosen measure of utilization (dollars vs. visits), (2) site of care (inpatient vs. outpatient), (3) patient age (child vs. adult), and (4) measures included in each adjuster category.

Results are derived from the RAND Health Insurance Experiment (HIE) and the RAND/New England Medical Center Medical Outcomes Study (MOS)

Source: Safran DG; Adjusting Capitation Rates Under Managed Competition ; January 1993 (prepared for U.S. Senate Committee on Labor and Human Resources). 

predicts utilization. This is because much of health care utilization is entirely unpredictable, due to unforeseeable health events that could not be anticipated even with a perfect set of adjusters. ${ }^{18}$ What remains of concern is that portion of utilization that is predictable based on patient characteristics. Risk adjustments made on this basis will work to avert "skimming" and reimburse appropriately those providers caring for sicker (or healthier) populations. ${ }^{17}$

The Jackson Hole Group stresses that, in the absence of mandatory HPPC participation for all small groups, it will be difficult to overcome the phenomenon of risk segmentation and skimming, even with risk adjustment. That is, small groups that have a favorable risk experience will opt to obtain coverage outside of the HPPC, leaving only the highest risk populations to be insured through the HPPC. To circumvent this problem, the Jackson Hole Group suggests that states statutorily impose identical rating rules for the small group market inside and outside of the HPPC. This will preclude healthy small groups from obtaining favorable ratings by going outside of the HPPC and will preserve economies of scale and risk diversity in the HPPC. ${ }^{17}$

Information Collection and Dissemination. Fundamental to the concept of managed competition is the availability of information on quality and price that can assist consumers in selecting the health plan best suited to their needs. Central to this process is the standardization of benefit packages and of information about them.

Each of the leading health care reform proposals that are based on a managed competition strategy recognize information to consumers as central to the plan and designate the HPPC as the agent responsible for the obtaining and disseminating information to consumers. The HPPC may contract out for this function.

The nature of the information to be collected and disseminated remains to be determined. Several tools that are appropriate to this task are currently being tested and dozens more are under development.

\section{HEALTH SYSTEM REFORM AND MASSACHUSETTS BUSINESSES}

Health Care as a Cost of Doing Business in Massachusetts. Costs for employee health benefits are only one of the many elements that affect the competitiveness of Massachusetts businesses. Variables such as cost and availability of labor, the cost of energy, state tax policy, state regulatory policy, and cost for unemployment insurance and workers' compensation all affect a state's competitive standing. However, Massachusetts employers remain particularly concerned about the Commonwealth's disproportionately high cost for employee health benefits. 

Based on recent research by the Massachusetts Taxpayers Foundation and on the results of its own employer survey, this task force's working group on Massachusetts businesses found that:

- Factors that influence the competitiveness of Massachusetts businesses vary both between industries and within industries.

- The cost of providing health care coverage to employees is an important factor to Massachusetts businesses, but is not the sole factor of importance.

- Massachusetts companies are disadvantaged in doing business by a combination of factors, induding but not limited to high health care costs.

- To improve competitiveness, state policymakers must work simultaneously on the wide range of factors that, taken together, shape the overall Massachusetts business dimate.

These observations in no way diminish the importance of immediate action on health care - they simply emphasize the need to take a multi-faceted approach to building economic development at the state level. Many leaders in the business community believe that health reform must bring Massachusetts health costs more in line with the national average.

A Business Perspective on Key Health Policy Issues. While there is no single business community position on health care reform, various opinion polls, surveys and statements from business associations indicate broad support for an approach that combines elements of both competition and regulation. Given a "managed competition" reform model, the business working group examined three policy areas: (1) mandates; (2) health care purchasing alliances; and (3) financing health system reform.

Mandates. Because of concems about equity, inefficiencies in care delivered to the uninsured, and private sector liability for cost-shifting under the current system, the working group condudes that all citizens must be required to have medical insurance. Given the diversity of views among employers on the subject of mandates, it would not be appropriate for the working group to endorse a specific course of action and present it as "the business community point of view". However, the group feels that a mandate - whether employer- or individual-based, or a combination of the two - will be required to guarantee universal coverage.

There was also consensus among the group that Massachusetts should not unilaterally implement an employer mandate. If the Commonwealth were to act alone and establish a mandate, it would only increase the competitive disadvantage for Massachusetts employers, who have to compete with businesses in other states 

without such a mandate.

Health plan purchasing alliances. While the issue of health plan purchasing alliances is dealt with separately in this report, this section highlights aspects of purchasing alliances that are of particular concern to Massachusetts businesses.

Taken together, insurance reform and the establishment of public-sector health purchasing alliances would have a profound effect on the Massachusetts business community. Proposed changes to the Employee Retiree Income Security Act (ERISA) could significantly curtail employers' ability to design, finance and manage employee medical benefit plans. That business working group is concerned about at least six factors that could result in strong disincentives to self-insure:

1. Allowing only corporations with more than 5,000 employees to manage their own health benefit plans.

2. Loss of market leverage for the relatively few companies that elect to selfinsure.

3. Weakening existing federal (ERISA) law, allowing state taxation and assessment self-funded plans.

4. Unrealistically low premium caps that will draw employers into regional alliances.

5. The ability of states to establish single-payer systems and other requirements that create problems for companies with multi-state operations.

6. Increased federal authonity over corporate alliances.

The task force working group believes that any Massachusetts system of purchasing alliances should be designed in such a way as to:

- Ensure the functioning of a pluralistic, consumer-driven insurance market that features multiple buyers with access to vital information on price and quality;

- Facilitate enforcement of small group insurance reforms and implementation of a nisk-adjusted reimbursement system that removes incentives for health plans to select risks;

- Maximize cost-conscious behavior on the part of businesses and individual consumers; 

- Maintain employer incentives to promote employee wellness and to develop new approaches to health benefit management; and

- Encourage innovation and competition in the insurance marketplace with an absolute minimum amount of bureaucracy and administrative overlay.

Consistent with these principles, the working group on Massachusetts businesses strongly recommends that companies with over 100 employees be allowed to selfinsure or to band together with other companies to form a private purchasing groups.

Employers feel that dominance of the health insurance marketplace by a single, public-sector buyer would stifle the competition and innovation that are central features of a successful managed competition model. The working group therefore concludes that assigning sweeping duties and authorities to a large, public-sector organization such as the regional alliance will neither encourage competition nor meet the needs of individual consumers.

Financing Health System Reform. Employers are concemed that promises of generous, guaranteed health coverage and targeted subsidies have raised public expectations conceming the perceived benefits of reform, without due consideration of the cost involved. If program costs are underestimated, or if projected savings do not materialize, private payers are likely to be viewed as sources for additional revenue.

If considering financing of the Clinton health plan in particular, the business community is concemed about:

- Underestimates of premium costs for the standard benefit package;

- Potential cost-shifting as a result of Medicare cuts;and

- The disposition of bad debt.

These concems about potential underfunding of federal health care reform and the prospect of hidden additional costs lead the business working group to conclude that it would be prudent to take a more incremental approach to universal implementation of a standard benefit package. Phasing-in comprehensive coverage over time would allow policymakers to more accurately assess actual costs to see if projected savings are realized, and to develop a more realistic plan to provide necessary revenues.

The working group emphasizes the critical importance of cost control because it recognizes that if left unchecked, runaway health care spending threatens the importance larger goals of health reform: to enhance the cost-effectiveness and quality of medical care, to ensure universal coverage, and to ultimately improve the health status of our citizens. 



\section{CHARACTERISTICS OF MASSACHUSETTS' HEALTH CARE DELIVERY SYSTEM \& PROJECTED IMPACT OF HEALTH SYSTEM REFORM}

Massachusetts' health care delivery sector is the largest of the four sectors that comprise its health care industry. The delivery sector employs $101 / 2$ percent of the Commonwealth's total work force. The other three sectors of the health care industry - medical equipment, drugs and health insurance - employ one percent of Massachusetts workers. (Table 16). The total (11.5 percent of Massachusetts' work force) represents a lower bound as a substantial percentage of persons employed in health-related research and education are excluded. U.S. Bureau of Labor Statistics data regarding research and education employment preclude disaggregation of those whose activities are health related. This section of the report examines the present, past and projected status of personnel and facilities that comprise Massachusetts' health care delivery sector. The section documents changes that have occurred over the past decade, and projects potential effects of health care system reform.

Health Care Delivery Personnel. As noted above, more than one of every ten Massachusetts workers is employed in the health care delivery sector. Only North Dakota (12.22 percent), Pennsylvania (11.08 percent) and Rhode Island (11.05 percent) have a larger portion of workers employed in health care delivery.

Until 1993, trends suggested a persistent growth of labor in the health care delivery sector that is uncharacteristic of any other sector or any other industry. In fact, between 1988 and 1992, while the Massachusetts economy lost 400,000 jobs, the health care delivery sector continued to grow, acquiring 36,849 new workers. Figure 2 contrasts the trends in the delivery sector with those in the other 3 sectors of the health care industry.

However, the rate of job growth appears to have slowed in 1993. Data for the first nine months of 1993 suggest an annual job growth rate of 2.9 percent, compared with an average of 3.6 percent for each of the preceding five years.

Sub-sectors of the Health Care Delivery Sector. The U.S. Labor Department dassifies the health care delivery sector into the following six sub-sectors: (i) hospitals, (ii) medical offices and clinics, (iii) nursing and personal care facilities, (iv) home health senvices, (v) medical laboratories, (vi) allied health senvices. Figure 3 indicates the relative distribution of labor among these six sub-sectors. As indicated, hospitals account for half of health care delivery sector jobs -4.9 percent of jobs statewide.

This classification of the health care industry derives from the sector definitions suggested and used by the Federal Reserve Bank of Boston. 

Table 16: Massachusetts Health Care Industry Employment by Sector, 1992

\begin{tabular}{l|c}
\hline Health Care Delivery & $10.53 \%$ \\
Health Insurance & $0.22 \%$ \\
Medical Equipment & $0.59 \%$ \\
Drugs & $0.15 \%$ \\
\hline Total & $11.49 \%$ \\
\hline
\end{tabular}

Source: $\quad$ U.S. Bureau of Labor Statistics, ES202 data tape, 1992 (Unpublished data) 

Figure 2

Health Care Industry Employment

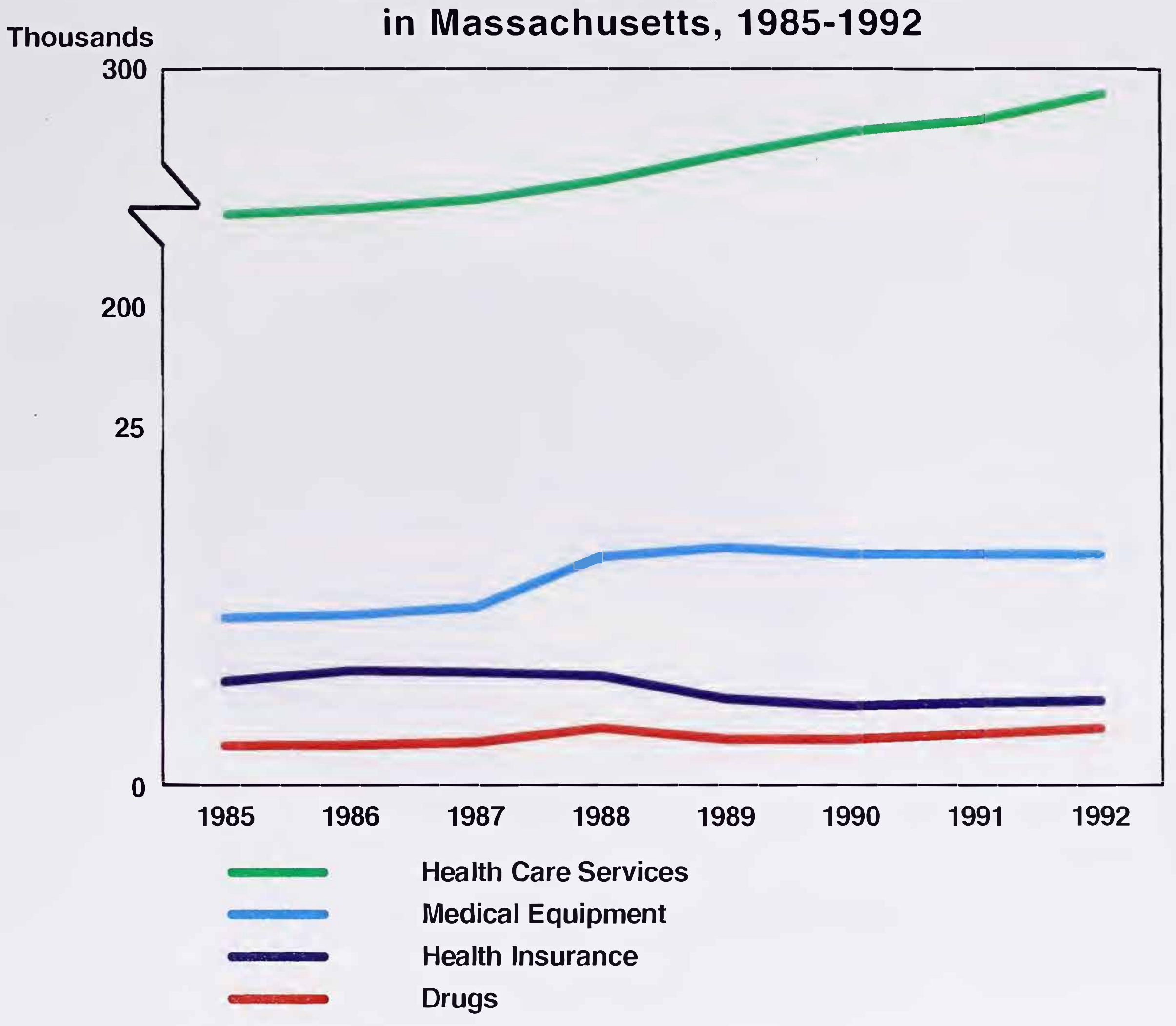





\section{Figure 3 \\ Health Care Delivery Employment by Sub-Sector, Massachusetts, 1992}

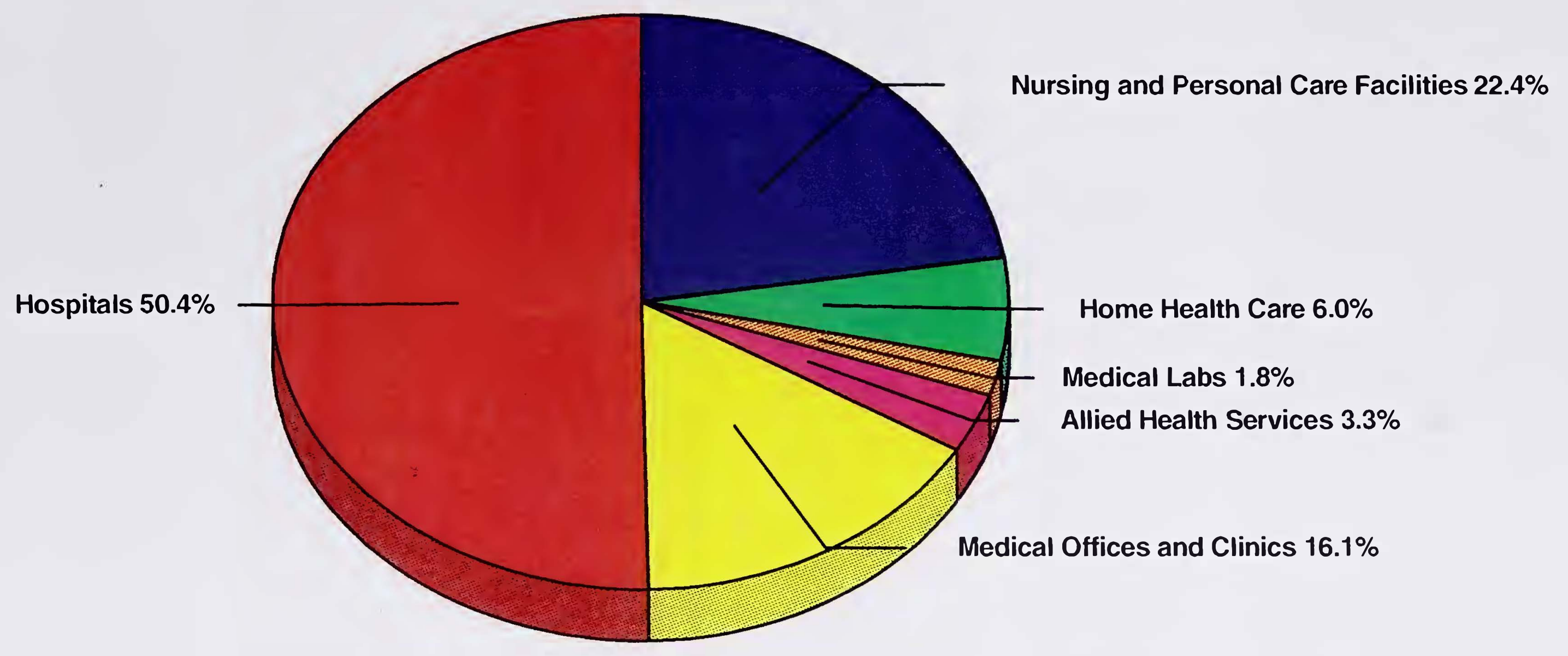

Source: U.S. Bureau of Labor Statistics, ES202 data tape, 1992 

Examining job growth in each of six sub-sectors of the health care delivery sector, one observes continuing growth in all but one (allied health services). However, average growth rates vary between sectors. (Figure 4) Between 1987 and 1988, a 40 percent surge occurred in medical office and clinic employment. This likely represents the effect of Medicare prospective payment, which affected a sizable shift in health care delivery from inpatient to outpatient settings. For similar reasons, one observes substantial growth in home health care services after 1988. In addition, a 1988 court ruling on Medicare eligibility for home health services, and subsequent revisions in Medicare eligibility rules, may have contributed to the observed growth in this subsector. $^{19}$ Between 1988 and 1992, home health care employment grew at an average annual rate of 16.8 percent.

Nursing employment. Hospital sector nursing jobs present one exception to the general health care labor trends described above. Figure 5 depicts the trends for hospital employed registered nurses (RN) and licensed practice nurses (LPN) between 1983 and 1992. While total RN positions were virtually unchanged over this period, there was a substantial substitution of part-time for full-time RN positions.

Among LPNs, approximately 4,000 jobs were lost between 1983 and 1992 . Job cuts were evenly distributed between part-time and full-time employees and occurred fairly consistently over the period. A study of post-prospective payment nursing trends in Massachusetts attributes the LPN job cuts to the introduction of an "all RN model" of nursing in Massachusetts hospitals. The report notes that salary differentials between RNs and LPNs at that time were negligible, making the retention of a mostly RN nursing staff a nearly cost-neutral shift. ${ }^{20}$

Interestingly, despite substantial nursing shortages in other health care settings, particularly in long-term care, nursing staff cut from hospital positions did not move into these jobs. ${ }^{21}$ Lower wages and higher patient loads in these settings may partly account for their inability to attract nursing staff previously employed in hospitals. While little is known about the ultimate employment shifts of these former hospital nurses, their failure to transition to non-hospital nursing employment points to the need for job transition assistance and retraining for staff dislocated during the coming period of health system reform.

Projected employment shifts in the health care delivery sector. Labor trends from the previous decade complicate efforts to estimate potential employment effects of health care system reform. To date, the health care delivery sector has resisted job loss and has continued to grow despite a decade of reduced hospital occupancy rates, admissions, lengths of stay and bed capacity, and despite a statewide economic recession.

Nonetheless, substantial job loss over the next several years is believed likely by health care industry analysts, labor economists and health care provider organizations alike. The majority of jobs cuts are expected to come from hospitals, the sub-sector 

Figure 4

Health Care Delivery Employment by Sub-Sector, Massachusetts, 1985-1992

Thousands

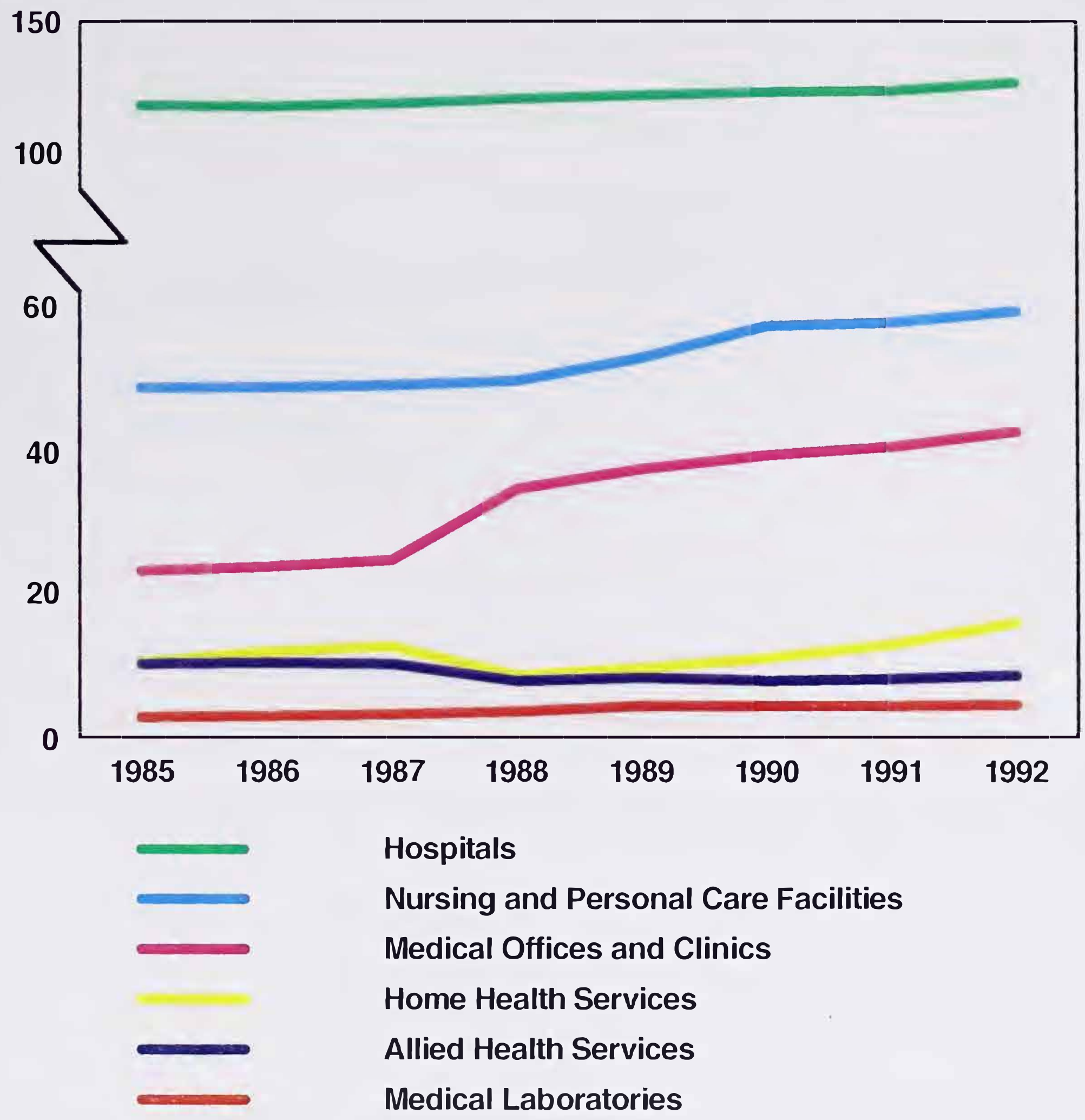

Source: U.S. Bureau of Labor Statistics, ES202 data tape, 1992 

Figure 5
-

Nursing Employment in Registered

Massachusetts Community Hospitals, 1983-1992

Thousands

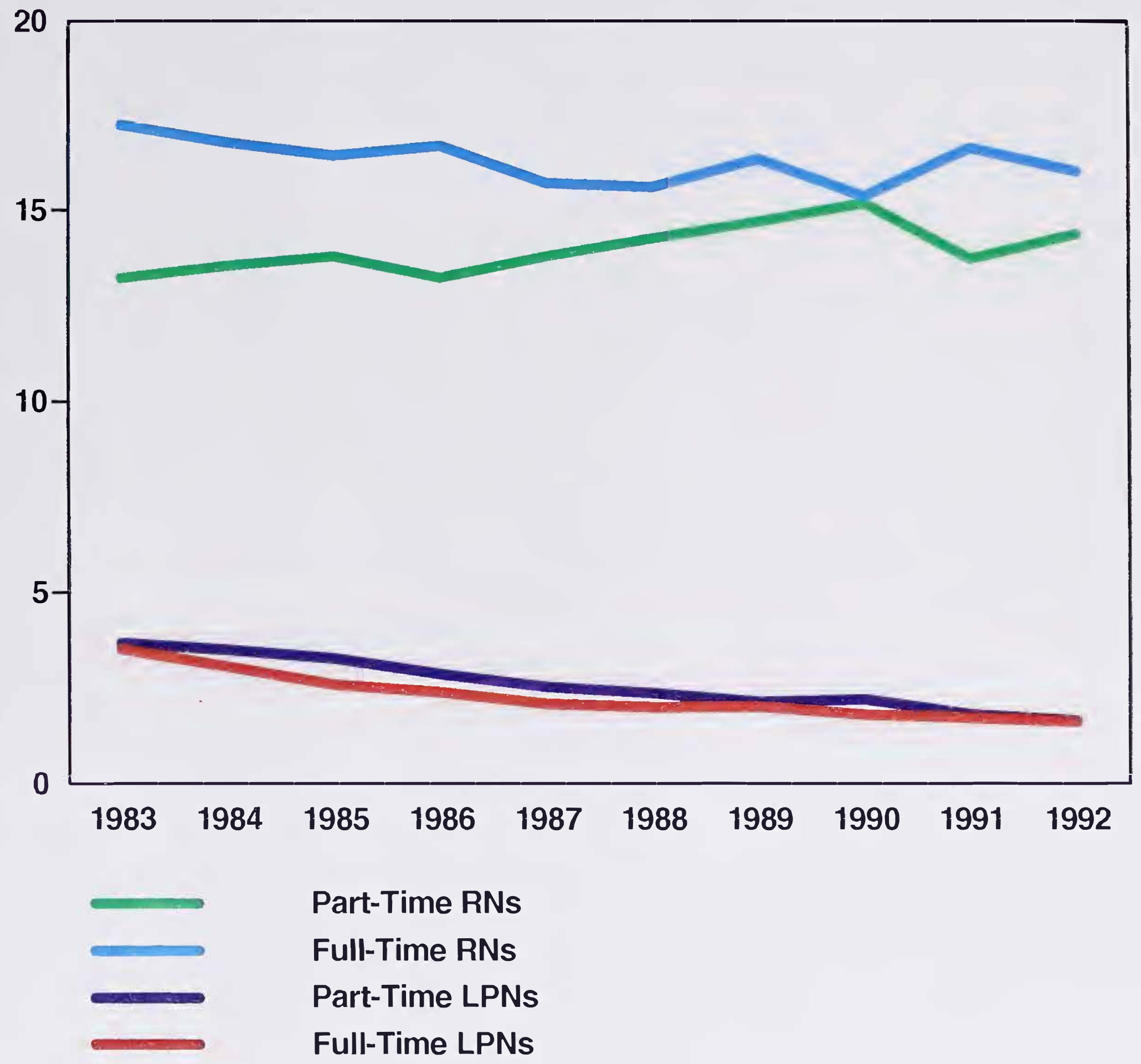

Source: Selected Hospital Statistics 1983-1992. Data from AHA Annual Surveys 1983-1992. 

which presently accounts for more than half of health care delivery sector jobs. Hospital job loss is expected to accompany bed closures as some hospitals close and others consolidate or downsize existing facilities.

For estimation purposes, this task force projected hospital employment curts as a function of potential hospital bed cosures. Note that these estimates are speculative and counter experience to date, where hospital bed closures have not resulted in substantial employment cuts. The absence of a relationship between bed closures and job loss in the past is attributed largely to the closure of relatively unoccupied and therefore minimally staffed - beds. In addition, past experience has allowed many hospital jobs to be transferred to other sub-sectors of health care delivery (e.g., ambulatory and long-term care) and to non-delivery sectors of the health care industry (e.g., research). Task force members agree that, unlike previous periods, bed closures during this time of health care system reform will result in hospital sector job loss. The number of hospital job curts is expected to exceed the capacity for reabsorption elsewhere in the health care industry. Table 17 estimates the range ofpotential hospital sector job cuts corresponding to hypothetical bed closures. The estimates presume an average of 4.5 job cuts per bed closure. This assumption takes into account current statewide staffing patterns.

Based on this methodology, the task force projects between 6,500 and 30,000 hospital sector jobs lost over the coming period of health care system reform. These estimates correspond with 1,440 and 7,783 hospital bed closures, respectively. The lower bound estimate presumes a 6.6 percent reduction in inpatient-days per capita the reduction necessary to bring Massachusetts inpatient rates in line with the U.S. average (i.e., 89.6 bed-days per 100 population). The upper bound estimate presumes a 35.6 percent reduction in inpatient-days per capita. This is the magnitude required to bring Massachusetts' rates in line with California, which currently has the lowest number of inpatient days per capita nationwide.

The actual number and pace of employment cuts will depend largely on the number and timing of bed closures. For individual hospitals, the magnitude of bed closures and associated job loss will depend on myriad factors including (i) the facility's present financial position, (ii) the facility's ability to compete successfully in a changing health care market place and (iii) the extent to which public and private constituencies are vested in and protective of the facility's future.

In addition, some portion of these hospital jobs are expected to be re-absorbed into other areas of the health care industry. For example, the increased demand for ambulatory care associated with universal coverage will likely result in increased employment in outpatient care settings. In addition, continued reductions in hospital admissions and lengths of stay are expected to increase demand for subacute care providers such as nursing homes, home health services and rehabilitation facilities. The potential scope of transitions from hospitals to other sectors of the health care industry is extremely difficult to estimate. Both lower wages and the need for 



\section{Table 17: Projected Hospital Bed Closures and Associated Job Loss'}

\begin{tabular}{l|l|l|l|l}
\hline $\begin{array}{l}\text { Standard to be } \\
\text { Reached by MA }\end{array}$ & $\begin{array}{l}\text { Percent } \\
\text { Reduction in } \\
\text { Annual Bed-Days } \\
\text { per Capita }\end{array}$ & $\begin{array}{l}\text { Required Bedt } \\
\text { Day Reduction }\end{array}$ & $\begin{array}{l}\text { Required Bed } \\
\text { Reduction }\end{array}$ & $\begin{array}{l}\text { Implied Hospital } \\
\text { Sector Job Loss }\end{array}$ \\
\hline United States & 6.59 & 381,560 & 1,440 & 6,480 \\
\hline California & 35.62 & $2,062,394$ & 7,783 & 30,024 \\
\hline
\end{tabular}

1 These estimates are entirely speculative. Employment effects are assumed to be a function of statewide hospital bed closures. Bed closure estimates are hypothetical, based on the estimated number of closures needed to bring Massachusetts inpatient bed-day rates in line with the U.S. average or with Califomia. 

substantial retraining may impede these shifts. For example, while increased need for primary care physicians is anticipated, it is undear whether physicians now employedas medical or surgical specialists will be attracted to these positions. A transition to primary care practice in an outpatient setting would represent a profound career change and would require substantial skill retraining. Evidence regarding hospital nursing job cuts in the 1980s (discussed above) indicates the difficulty of attracting health care professionals to delivery jobs which require substantially different skills, involve caring for a different patient population in a different setting, and offer lower compensation.

Task force members liken the coming need for health system labor transitions to recent experiences in the defense, banking and high-tech industries. While task force members have limited expertise and knowledge of how these transitions have been made, they commend consideration of these models and consultation with leaders in these areas. In addition, task force members note the importance of monitoring the training of new entrants to the health care industry to ensure orientation and skills consistent with projected market demands.

Finally, job loss in the health care delivery sector is expected to impact businesses beyond the health care industry. However, the magnitude of uncertainty regarding the scope of health care industry job loss predudes estimation of these cross-industry effects.

Health Care Delivery Facilities. During the past decade, Massachusetts' health care delivery facilities and utilization of them have undergone profound change. As indicated earlier, the decade saw deliberate and persistent movement of care from inpatient to outpatient settings. Figure 6 depicts the significant dedine in inpatient utilization and the concurrent rise in outpatient care over this period. The trends are attributable to a combination of factors induding the introduction of prospective payment, increased managed care penetration and an economic recession that heightened attention to health care cost-containment.

The impact on each of the six sub-sectors of the health care delivery sector has been considerable. The previous section described the manifestation of these trends with respect to employment changes in each sub-sector. The impact on delivery facilities is more difficult to document as, with the exception of hospitals, data are exceedingly limited. However, two broad categories of facilities - hospitals and essential community providers - are regarded as potentially most vulnerable duning the coming period of reform. The following section details available evidence regarding the past and projected impact of health system reform on these Massachusetts health care providers.

Hospitals. There are currently 150 registered hospitals in Massachusetts. As profiled in table 18, the majority ( $N=93)$ of these are general, acute care hospitals. In addition, there are 6 specialty acute care hospitals, 24 specialty hospitals for psychiatric care 

Inpatient and Outpatient Utilization, Massachusetts, 1983-1992

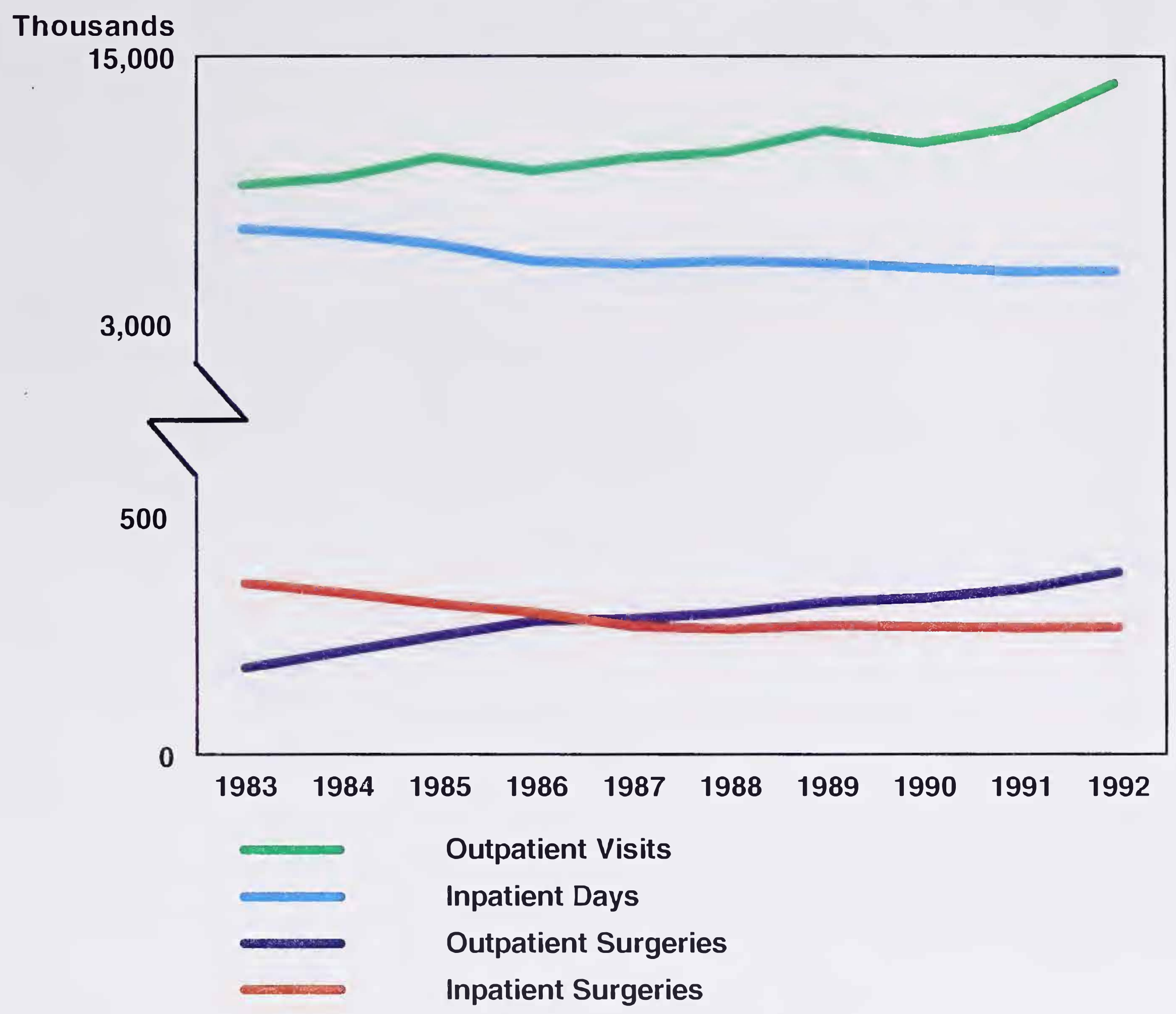

Source: AHA Hospital Statistics, 1983-1992 

Table 18: Massachusetts Hospitals by Type of Care and Governance, 1994

\begin{tabular}{l|c}
\hline Type of Care & \\
Aarte Care & 93 \\
General & 6 \\
Specialty & 24 \\
Psyctiatric and Substance Abuse & 12 \\
Chronic and Long-Term Care & 10 \\
Rehabilitation & 5 \\
Other & 150 \\
TOTAL & \\
& \\
Hospital Governance & \\
Private, Not-for-Profit & 98 \\
Investor-Ouned, For-Profit & 16 \\
Federal & 5 \\
State & 17 \\
Country & 5 \\
Municipal & 9 \\
TOTAL & 150 \\
\hline
\end{tabular}

Source: Massachusetts Hospital Association, 1994 

and substance abuse treatment, and 27 hospitals for chronic or long-term care. Two thirds of Massachusetts hospitals are voluntary facilities (i.e., private, non-profit, govemed by a board of trustees). There are 36 hospitals run by the federal $(\mathrm{N}=5)$, state $(N=17)$, county $(N=5)$ or municipal $(N=9)$ govemment. The remaining 16 hospitals are investor-owned (for-profit) facilities. Most of these are specialty hospitals providing psychiatric care and substance abuse treatment.

Hospital Closures, Conversions, Mergers and Acquisitions. Since 1986, 17 Massachusetts hospitals have closed. Seven of these were state or municipal facilities, for whom closure was the final step in a privatization process that began with downsizing through incremental bed closures. At the time of closure, each facility had 100 or fewer beds (down from original sizes of over 500 beds). ${ }^{22}$

The other nine hospitals that closed since 1986 were small ( $<100$ beds) private, nonteaching, acute and chronic care facilities. The hospitals were located primarily in the Boston metropolitan area and closed in response to an excess bed capacity.22 Since 1975, there have been approximately 12 hospital mergers in Massachusetts. These were in response to the changing health care environment, which called for linkage to managed care networks and increased cost efficiencies that could be achieved through combining administrative functions. Other than the recently announced merger between Brigham and Women's Hospitals and Massachusetts General Hospital, mergers have involved small to mid-sized, non-teaching hospitals with immediate geographic proximity to one another. ${ }^{22}$

Acquisitions and affiliations are more recent phenomena in Massachusetts. There have been seven to eight acquisitions since 1990. Three of these were small, municipal acute care hospitals whose survival in the increasingly competitive market was threatened. They were purchased by larger, private acute care hospitals. ${ }^{22}$ And since 1992, there have been 11 official hospital affiliations in Massachusetts.

Affiliations have typically involved an agreement between a small community hospital and a larger teaching or community facility. The number of affiliations is expected to continue as health system reform increasingly compels provider networks.

Since 1987, eleven acute and chronic care hospitals were converted to nursing homes, rehabilitation hospitals or outpatient facilities. This trend reflects the systemwide shift away from inpatient care heralded by prospective payment.

Substantial restructuring of Massachusetts hospitals is expected to continue as health system reform proceeds. The previous section on projected hospital labor effects indicates the range of hospital bed closures that might be necessary to bring Massachusetts inpatient utilization to any of various standards. The extent to which bed closures will actually occur and the balance of mechanisms through which they will be achieved (e.g., site closures, mergers, affiliations and acquisitions) remains largely unpredictable. The added vulnerability of Massachusetts' hospitals involved in 

medical education and research is described separately. (See page 51, "Health Related Research and Education".)

Community Hospitals....... This section describes salient features of and projected trends for Massachusetts community hospitals. Community hospitals are defined as all non-teaching hospitals in the Commonwealth.

Massachusetts has a broad network of community hospitals that offer local access to quality hospital care and treatment. Many of these hospitals serve as the principal economic and health resource in their community. They often are the largest employer and provide an array of community health services beyond traditional hospital care. Collectively, community hospitals in Massachusetts employ more than 60,000 people, account for almost 550,000 admissions per year, and make up 55 percent of total hospital expenditures statewide. Costs in the state's community hospitals compare favorably with those of community hospitals in other states.

Community hospitals in Massachusetts already have begun to adapt to the changing health care environment. As noted above, many have merged with neighboring facilities or developed affiliations with teaching hospitals. Community hospitals have also expanded their efforts to respond to local health needs, often working in collaboration with other local health and service agencies. Many community hospitals also own or operate nursing homes, visiting nurse associations, and other health organizations. And community hospitals are forming new partnerships with local groups of physicians.

Under the various health reform proposals before Congress, community hospitals are expected to expand their collaboration with other hospitals and health organizations. Community hospitals will become a key part of new "health networks" that will be paid on a capitated basis by govemment programs and insurers. Although community hospitals will face increased financial pressure under this changed payment system, many community hospitals in Massachusetts will continue to play active roles in a reformed health care environment.

Essential Community Providers. Essential community providers, broadly defined, include institutions and organizations that provide care for populations whose social, financial and/or geographic position othenvise imposes difficulty with respect to obtaining needed health care services. The various federal health care reform proposals before the U.S. Congress differ in the extent to which they identify an explicit role for essential community providers. The Clinton reform proposal gives states broad authority to define and identify essential community providers, but

Information for this section on community hospitals was provided by the Massachusetts Hospital Association, February 1994. 

stipulates the indusion of all Public Health Service Act grantees (e.g., community health centers, title $X$ dinics). The plan requires all insurance plans to contract with essential community providers for at least five years. After that period, plans may apply for a waiver to terminate their contacts with essential providers if there is evidence that vulnerable populations are being adequately served.

Members of this task force note that without purposeful attention to the unique role (and the associated costs) of essential community providers, their viability may be threatened during health system reform. Without the survival of these providers, the populations they presently serve may be greatly disadvantaged by health system reform.

The added costs associated with caring for the populations served by essential providers stem from the complex interrelationship among social and health factors that manifest in unique health system needs. These providers are uniquely experienced in addressing the myriad health problems that pervade communities where poverty rates are high and educational attainment is low. The bamiers to care that these populations experience are not generalizable to other patient populations. Bamiers range from the logistic (e.g., lacking transportation, having job and child care constraints that conflict with medical office hours), to the cultural, the linguistic, and the financial. In response, community health centers and other essential providers integrate services that address these unique population needs. Many offer transportation assistance and translation services. All put special emphasis on casemanagement, health promotion and education, outreach, nutrition and preventative care. In addition, many offer social services that are essential to their populations such as social support, family planning, child care, and home visiting senvices. ${ }^{23}$

Essential Community Providers and Local Economies. In addition to serving a vital social function, many community health centers and other essential community providers are integral to the local economy of the neighborhoods they serve. In many cases, centers are the largest employer in their community. The following description of the Bowdoin Street Health Center illustrates the point:

"The Bowdoin Street Health Center is located in a poor, culturally diverse community in Dorchester. The business district encompasses Bowdoin Street and Geneva Avenue and is sandwiched between Fields Comer and Upham's Comer. Most of the businesses in this district are small businesses owned by local residents. The health center, govemed by a community Board of Directors (10 are health center patients), is the largest employer in the neighborhood. It employs 50 people; half of whom live in the service community. Bowdoin street provides care to $25 \%$ of the 23,000 residents in the area and has been doing so for the last 20 years. The center provides services in four languages: English, Spanish, Cape Verdean Creole, and Haitian Creole. At least $40 \%$ of the adults and $20 \%$ of the children in the community do not 

have a usual source of primary care. The center employs a team of community health workers who contact every household, make referrals for primary care, help residents to organize to prevent violence, develop open space, promote \& sustain local businesses, and forge partnerships between the city's resources and the neighborhood's interests \& needs. The health center has also developed an occupational health/primary care practice to address the health needs of the employees of many of the manufacturing companies in the area. These employees, mostly people of color, are now able to access primary care services in their neighborhood and in their language. They can be treated for any work related injuries or illnesses they incur on the job. The health center plays a significant role in the revitalization of the business and residential neighborhood." (Adela Margules-Executive Director)

Essential Community Providers and Health System Reform. Health system reform is expected to bring essential community providers into direct competition with other provider organizations who might choose to locate offices in these communities. Enhanced choice among providers may bring a tremendous advantage to otherwise poorly served communities. However, price cannot be the sole determinant of providers' eligibility for serving these populations. Qualification must indude evidence of providers' capacity to deliver the spectrum of interrelated social and health services required in providing high quality, effective health care to these populations.

While reform offers these providers the opportunity to innovate and redesign the way in which care is currently provided to vulnerable populations, their present financial condition would predude many from effectively competing against larger, more fiscally secure provider organizations. Federal or state support in the form of grants or loans, will be essential to enabling these community providers to invest in network development, infrastructure, ${ }^{24}$ personnel and improvements in access and quality.

Finally, most federal reform proposals under consideration indude provisions for risk adjustment formulae. As discussed elsewhere in this report, risk adjustment is regarded as essential to avoiding risk segmentation and ensuring appropriate reimbursement of providers that serve more resource intensive populations. Without adequate attention to the unique costs associated with providing care to these populations, the quality and availability of this care will be threatened as providers either curtail essential senvices or lose financial viability.

\section{HEALTH-RELATED RESEARCH AND EDUCATION}

Health-related research and education are vital and integral elements of Massachusetts' health care industry. A large share of the nation's medical research, education and training is carried out in Massachusetts. The Commonwealth (and Boston, in particular), have led work in medical education and research - pioneering 

medical advances such as the treatment of cancer through chemotherapy and hypothermia, and the use of laser surgery.

Health delivery and finance changes over the past several years have placed substantial pressure on the academic medical community. Teaching hospitals face restrictions in financial resources initiated by the shift away from cost-based reimbursement. The introduction of Chapter 495 legislation has forced teaching hospitals to accept both indemnity and managed care contracts that often fail to account for the additional costs associated with their research and education missions.

Medicare graduate medical education payments, another source of revenue for teaching hospitals, have also been reduced, causing teaching hospitals to shift costs to private payers. Private payers increasingly resist these cross-subsidies, leaving teaching hospitals increasingly financially vulnerable.

Price competition and capitation compel teaching hospitals to make significant shifts in their costs structure. These are expected to result in downsizing and layoffs described elsewhere in this report.

These combined factors and trends challenge the Commonwealth's ability to "hold harmless" its research and education activities during the coming period of health system reform.

Health-Related Research. In 1993, the Commonwealth received an estimated $\$ 854$ million in federal research money from the National Institutes of Health (NIH).

Additional sums were received from other federal agencies, state govemment and private funding sources, but no precise estimates for these are available. However, state and private sources are believed to contribute less than 20 percent of total research dollars.

Massachusetts has traditionally been extremely effective in competing for federal research funds. In 1993, Massachusetts received 10 percent of all research funding from the National Institutes of Health $(\mathrm{NIH})$. Only Califomia and New York received a larger share of NIH research money.

Of total NIH dollars received in 1993 (\$854), 43 percent were awarded to hospitals and 57 percent to universities and research institutes. The $\$ 365$ million received by Massachusetts hospitals represents more than half of all NIH funds awarded to hospitals nationwide. Five Massachusetts hospitals accounted for 80 percent of this funding - receiving a combined 43 percent of all NIH funds awarded to U.S. hospitals. Universities and research institutions received $\$ 489$ million from NIH in 1993.

Projected Research Funding Trends. Although Massachusetts' annual NIH funding continues to grow, several studies suggest that, after adjusting for inflation, federal 

research dollars have been dedining for several years. ${ }^{25,26}$ In addition, a recent report on academic health centers found that federal funding does not fully cover the costs of research. The report indicates that one-third of dinical research activity is funded through cross-subsidized patient care revenues. ${ }^{27}$

An additional strain on research funding may come through reduced indirect funding allowances. Indirect costs caps on research institutions are anticipated under health system reform. Indirect costs associated with research typically indude such items as building space and utilities, hazardous waste disposal, radiation safety and administration. Allowances for the administrative portion of indirect costs were recently capped at 26 percent. Work from the Boston Organization of Teaching Hospital Financial Officers (BOTHFO) suggest that current administrative caps fail to fully cover the costs of administration in Massachusetts research institutions. ${ }^{28}$ Further reduced indirect cost caps - or caps that are based on a national average - threaten the viability of Massachusetts research institutions' endeavors.

Two additional concerns are the expected level and mechanisms for federal research funding. Under the Clinton plan, health-related research would continue to be funded through the federal appropriations process. This mechanism is unpredictable and slow to respond to changing scientific priorities and needs. An approach more beneficial to research would designate a small percentage of funds spent on health care services for research and development activities. Such monies could be funnelled through a trust fund and allocated through existing peer-reviewed methods. While the precise dollars to be allocated for research remain unknown, the Clinton proposal suggests increased funding for research on prevention, health promotion and health senvices. There are no stipulations with respect to the funding of biomedical research.

Potential Employment Effects of Reduced Research Funding. The precise number of individuals employed in health-related research is difficult to ascertain. The difficulties are particularly pronounced in hospital settings, owing to the tripartite functions of many hospital employees involved in research (i.e., research, education and patient care). These multiple roles make it difficult to link direct research funding to direct and indirect job creation.

In universities and research institutions, it is somewhat more feasible to estimate the employment effects associated with research funding. The $\$ 489$ million received from $\mathrm{NIH}$ by these organizations likely funds between 5,900 and 8,600 employees.

This assumes that between 60 and 70 percent of direct research dollars are spent on labor and that the average research salary is between $\$ 40,000$ and $\$ 50,000$ per year. 

Applying the same assumptions to research funds received from private corporations and foundations, these dollars likely account for between 2,000 and 6,250 jobs.

Cross-Industry Stimulus of Health-Related Research. Available data preclude estimation of indirect job creation and induced spending attributable to health-related research and education. However, previous evidence indicates that these cross industry effects do occur. For example, academic research is shown to have a positive effect on commercial productivity in the pharmaceutical industry - with local pharmaceutical companies benefiting disproportionately from the presence of academic research. ${ }^{20}$ In addition, university research is observed to significantly effect corporate patents, particularly in the areas of drugs, medical technology, electrics, optics and nudear technology. ${ }^{30}$

Another tangible indication of the economic impact of research is the numerous biotechnology firms that have "spun-off" from university research activities. According to the Massachusetts Biotechnology Council, there are 226 biotechnology firms in Massachusetts; 43 percent of these are in the early stages of development. In 1992, Massachusetts biotech firms raised roughly $\$ 1$ billion in capital, received a total of $\$ 1.85$ billion in total industry revenue and spent nearly $\$ 2.4$ billion on research and development, manufacturing and administrative activities. Employment in Massachusetts biotechnology firms - now estimated at 17,600 - grew 16 percent between 1992 and 1993. While the Governor's Council on Economic Grouth and Technology has a separate task force devoted to the biotechnology industry, the substantial interdependence between this industry and Massachusetts' health-related research sector is of relevance here.

Further study of the direct and indirect economic impact associated with health-related research and education is clearly warranted. Similar studies commissioned by public officials elsewhere have yielded valuable information and contributed to the debate over the economic impact associated with health-related research and education. ${ }^{31}$

Graduate Medical Education. Massachusetts has four accredited medical schools, 46 hospitals that have residency programs approved by the American Council on Graduate Medical education and 19 hospitals categorized as academic medical centers. In 1993, Massachusetts trained approximately 3,027 medical residents - 3.5 percent of the U.S. total. Medicare revenues for graduate medical education (GME) totaled $\$ 300$ million. An additional $\$ 508$ million of GME was financed by other payers. $^{32}$

Medicare has reimbursed teaching hospitals for the direct and indirect costs associated with teaching since its inception in 1966. Direct medical education (DME) expenses compensate hospitals for the direct costs associated with medical training (e.g., medical residents' salaries, benefits, faculty salaries, overhead). Indirect medical education (IME) expenses are intended to compensate hospitals for the indirect costs 
associated with teaching (e.g., reduced physician productivity due to teaching responsibilities, increased laboratory and testing associated with teaching, costs of providing highly specialized care to more severely ill patient populations).

Over the past several years, funding for graduate medical education has been substantially reduced. Between 1986 and 1989 Medicare made several reductions in the indirect medical education (IME) rate, bringing it from 11.89 to the current 7.7. Medicare also reduced the residency training allowance for direct medical education (DME) reimbursement from full costs (currently averaging $\$ 95,000$ ) to a hospital specific allowance averaging $\$ 67,000$.

Proposed federal reforms would impose further reductions of unprecedented magnitude. The Clinton reform proposal would reduce the IME rate to 3.0 and impose a cap of $\$ 62,000$ for Massachusetts' DME. In addition, the Clinton plan would reorganize the mechanisms through which GME funds are obtained and distributed. GME funds would come through surcharges on premiums for all payers - no longer just Medicare. The current DME and IME mechanisms would be replaced by two new funding pools.

An analysis released by a coalition of Massachusetts' teaching hospitals (induding the Boston Organization of Teaching Hospital Financial Officers) found that the level of GME funding proposed by Clinton would result in a $\$ 1.9$ billion shortfall to Massachusetts teaching hospitals between 1996 and 2000. Most (\$1.2 billion) would be attributable to Medicare changes and $\$ 700$ million would be due to changes in GME funding from private payers. ${ }^{32}$ Of the $\$ 1.2$ billion Medicare curt, $\$ 727$ million is attributable the reduced IME rate described above (i.e., 7.7 to 3.0).

In addition, the teaching hospital coalition challenges the assumptions underlying the administration's proposed IME cuts. IME reductions assume that 50 percent of current IME payments are used to finance free care and bad debt - which would purportedly be eliminated through universal health coverage. The teaching hospital coalition challenges the magnitude of these cuts, stating that much less than 50 percent of IME will be offset by eliminating uncompensated care. The coalition indicates that IME is largely required to compensate teaching hospitals for the disproportionately severe patient populations served - a feature that will be not be mitigated by universal coverage . ${ }^{32}$

Summary Comment. The distinguished position of Massachusetts research and teaching institutions is testimony to the quality of their work. This is evident in the success of local academic institutions in attracting national research funds. Most of these are won in peer-reviewed competition against proposals from states throughout the country. Massachusetts health-related research thrives when scientific merit and quality determine the allocation of federal research funds. Similarly, local training institutions compete extremely effectively for medical students and residents, and are 

likely to continue to do so as long as funds continue to be awarded on an open, competitive basis. Massachusetts representatives and officials should work forcibly against any federal efforts to redistribute research and/or training dollars on the basis of geographic equity rather than technical merit.

Regardless of these efforts, substantial cuts in federal funding for graduate medical education and reduced research funding are expected. The magnitude will likely exceed the Commonwealth's fiscal capacity to directly compensate for the losses. However, the state could play a role in facilitating any number of creative solutions to assist in recouping losses incurred through federal cutbacks. These indude (1) aggressive efforts to raise private funds to support new biomedical and health services research ventures in Massachusetts, (2) the issuing of state bonds to fund rehabilitation and renewal of existing research facilities (particularly if the federal govemment proceeds with indirect cost cuts), and (3) the establishment of a small percentage set-aside from health care premiums for purposes of research and medical education.

\section{RECOMMENDATIONS}

To assure consideration of the full spectrum of economic costs and benefits associated with the Massachusetts health care industry, this task force has purposefully included a membership of three dozen individuals from businesses within and outside of the health care industry. Owing to the diversity of interests represented, there are only a small number of issues about which the group achieved consensus. The following recommendations indicate these points of consensus.

Universal Coverage. Achieving universal health coverage - health insurance for all Massachusetts residents - must be a principal goal of health system reform.

Task force members are united in the view that all Massachusetts residents must have health insurance, both for reasons of social equity and to eliminate the cost shifting and system inefficiencies that result from uninsurance. Task force members agree that some form of health insurance mandate will be required to attain universal coverage. The group did not reach consensus on the appropriate mechanism - or combination of mechanisms - through which a mandate should occur.

Although task force members neither endorse nor denounce an employer mandate, some task force members fear that Massachusetts businesses' competitiveness will be harmed if Massachusetts acts alone in implementing an employer mandate.

Non-Group Insurance Reform. Related to the goal of universal coverage, is the need for non-group insurance reform. The need for non-group insurance will persist under either an employer or individual mandate - or under continuation of the status 

quo. Reforms in the non-group insurance market are required to assure the availability and affordability of non-group coverage.

Task force members agree that objectives mirroning those in the Commonwealth's small group insurance reform should be pursued in the non-group market. These include guaranteed issue and renewal of non-group policies, a uniform set of benefits available to all non-group applicants, limitations in the allowable premium vaniations across the non-group market, and restrictions on the imposition of waiting periods and pre-existing condition exclusions.

While these changes may help stabilize and assure the availability of non-group coverage, they are unlikely to make non-group coverage more affordable. Evidence from small group insurance reform indicates that the changes affected the availability, but not the affordability, of coverage. Thus, the task force members agree that, for universal coverage to be achieved, subsidies will be required to assist those low income individuals and families who must buy coverage in the non-group market. The group did not reach consensus on the mechanisms through which subsidies should be funded.

Essential Community Providers. The task force recognizes that there are provider organizations and institutions in Massachusetts that serve populations whose social, financial and/or geographic position otherwise impedes access to timely and effective care. The task force further recognizes that the viability of these essential community providers may be threatened during health system reform if the unique demands (and associated costs) of caning for these populations are not adequately recognized and addressed. Without these providers, the populations they currently serve may be further disadvantaged by health system reform.

Accordingly, the task force recommends that, in the immediate term, the Commonwealth take at least three steps:

(1) Adopt mechanisms to assure the stability and viability of existing essential community providers duning health system reform. Mechanisms could indude an initial period duning which insurers would be required to contract with existing essential community providers. After a defined period, insurers could apply to waive these contracts if there was evidence that populations were being adequately served.

(2) Establish standards of care to be applied to any and all providers seeking to serve these populations. Standards should specity services and practice norms required to assure access to and effectiveness of care in these populations. Required services could vary by community or population, but would specify senvices necessary to overcome logistic, linguistic, cultural and financial barriers to timely and effective care. 

(3) Ensure adequate payment for added senvices. To assure the continued viability of essential community providers, the cost of added senvices (specified above) that would be required must be covered either through direct financial support to provider organizations or through risk adjustment formulae applied to premiums for the populations served.

Health Alliances. Task force members do not uniformly agree on the need for statewide health plan purchasing alliances. However, if the Commonwealth adopts a strategy involving purchasing alliances, task force members recommend that alliances be structured as nonprofit corporations with employer and consumer boards of trustees, reflecting their primary function as an agent for the consumer. The task force also recommends that, to the greatest extent possible, alliances contract with the private sector to perform essential functions (e.g., premium collection and distribution, data collection, analysis and reporting). Most specifically, task force members recommend that premium funds not pass through the alliance. Rather, a bank or investment company, contracted through the alliance, is suggested as the appropriate mechanism. Some degree of state oversight would be required to assure the adequacy of access and quality of care to populations served through the alliance.

If health alliance participation occurs on a voluntary basis, the task force strongly recommends that the state assure identical premium rating rules within and outside of the alliance. In the absence of identical rating rules, coverage through the alliances would grow increasingly expensive as all but the highest risk populations would be drawn outside of the alliance. This would negate the risk pooling function that alliances are intended to serve.

Cost Control. The task force recommends that the Commonwealth take no regulatory steps toward health care cost control at this time. Recent evidence that health care cost inflation is moderating and approaching general rates of inflation are encouraging. The task force believes that market pressures will continue to drive down the rate of cost increases as purchasers press for lower rates of health care cost inflation and lower costs overall. As these pressures continue to drive the restructuring of Massachusetts health care delivery system, the downsizing of existing facilities and continued redirection of care from inpatient to outpatient settings may bring health care expenditures closer to those of the Commonwealth's economic competitors and the U.S. overall. The need for regulatory cost control mechanisms at the state and/or federal levels should be reconsidered in three to five years.

Job Training Funds. The task force recommends that a portion of state funds for job training and education in health care be redirected to assist individuals displaced during health system reform. As described, the majority of health care industry job cuts are expected to oocur in hospitals. A portion of these jobs may be successfully redirected to outpatient and long-term care settings. However, the nature of the tasks and populations served may demand retraining of health care delivery personnel 

transferred to these settings. In addition, alternative job skills and career possibilities will be needed by those for whom jobs elsewhere in the health care industry are unavailable. Training for new entrants to the health care industry should be monitored to ensure consistency and compatibility with the projected market.

Graduate Medical Education. The congressional delegation should press for retention of the current indirect medical education (IME) payment rate. Retention of the current IME rate could be made contingent on demonstrated progress toward increased training of generalist (primary care) physicians and/or re-training of specialists for these roles. No reductions in the rate should be made until universal health coverage is achieved. After universal coverage is achieved, some reduction in the IME rate may be appropriate, but reductions should not be of the magnitude currently proposed.

Proposed reductions in IME assume that the majority of IME presently supports uncompensated care, which would be eliminated with universal coverage. The task force finds compelling evidence that this assumption overestimates the application of IME to support uncompensated care. IME is needed primarily to compensate teaching facilities for their disproportionately high share of severely ill patients. Universal coverage is not expected to reduce the case-mix in these facilities - and may increase it.

Health-Related Research. Task force members agree that the Commonwealth's health-related research sector is a valuable economic resource as well as a source of distinction and prestige. The myriad ways in which funds for health-related research are at risk have been described. The task force recommends an active role for the Commonwealth in protecting and advancing federal and private financial commitments to research. Toward this end, the task force identifies three potential roles for the Commonwealth:

(1) Members of the congressional delegation should press to retain current federal indirect research cost allowances. Recent caps on the administrative portion of indirect costs are already leading to funding short-falls. Further cuts in the indirect cost allowances would make it increasingly difficult for many of Massachusetts' leading research institutions to sustain the viability of their federally sponsored research efforts.

(2) Members of the Massachusetts congressional delegation could press for a national research trust fund, with monies to be allocated through the traditional peer review process based on technical merit. The research trust could be funded with a percentage set-aside of health insurance premiums nationwide. This would dissociate the availability and scope of federal research funds from the annual vicissitudes of the congressional appropriations process. 

(3) The Commonwealth could assume a more active role in raising funds for health-related research conducted in Massachusetts universities, hospitals, and research institutions. This issue will grow increasingly important if cuts in federal indirect research cost allowances proceed and/or if overall levels of federal research spending fail to keep up with inflation.

Competition for federal and private research dollars is expected to gain intensity. If Massachusetts fails to compete effectively for these funds, other states will gain both the funds and spin-off products and industries that currently benefit our economy. Task force members suggest that the Commonwealth take an aggressive position to support continued and enhanced federal and private research funding and to assure that monies continue to be allocated through the peer review process. Massachusetts research thrives on its ability to compete on the technical merits of its applications. 



\section{REFERENCES}

1. Levit KR, Lazenby HC, Cowan CA and Letsch SW. Health spending by state: new estimates for policy making. Health Affairs 1993; 12(3):7-26.

2. U.S. Congressional Budget Office. Behavioral assumptions for estimating the effects of health care proposals. Washington D.C., November 1993.

3. U.S. General Accounting Office. Health care spending: nonpolicy factors account for most state differences. Washington D.C., February 1992.

4. Greenfield $S$, Nelson EC, Zubkoff $M$, et al. Vaniations in resource utilization among medical specialties and systems of care. JAMA 1992; 267:1624-1630.

5. Manning WG, Leibowitz A, Goldberg GA, Rogers WH, Newhouse JP. A controlled trial of the effect of a prepaid group practice on the use of services. N Engl J Med $1984 ; 310: 1505-1510$.

6. American Hospital Association. AHA Hospital Statistics, 1992-1993 Edition: A Comprehensive Study of U.S. Hospitals. Chicago IL: American Hospital Association, 1992.

7. A Foster Higgins Inc. 1992 Health Care Benefits Survey, Table 79, May 1993.

8. Group Health Association of America. HMO Industry Profile. Washington D.C., 1992.

9. Employee Benefits Research Institute. Sources of health insurance and characteristics of the uninsured: Analysis of the March 1992 Current Population Survey. January 1993.

10. Blendon RJ, Donelan K, Thorpe KE, et. al. Final Report: A Household Survey of the Health Insurance Status of Massachusetts Residents. October 1990.

11. Massachusetts Association of HMOs. Facing fiscal reality: a proposal to increase affordability and accessibility of health insurance in Massachusetts. November 1992.

12. Jeffrey Ritter, Commissioner, Massachusetts Department of Medical Security, personal communication.

13. See, for example, policy statements from associations such as the Washington Business Group on Health, the U.S. Chamber of Commerce, and the Massachusetts Business Roundtable.

14. Enthoven A, Kronick R. A consumer-choice health plan for the 1990s. N Engl J Med 1989; 320:29 -37. 

15. Jackson Hole Group. Govemor's Guide to Forming and Implementing Health Plan Purchasing Cooperatives. Presented at the National Governors' Association Workshop, Washington D.C., December 9, 1993.

16. U.S. Department of Commerce, Bureau of the Census, County Business Pattems: 1991; In press: January 1994.

17. Safran DG. Adjusting Capitation Rates Under Managed Competition; The Health Institute, New England Medical Center; Boston, MA; January 1993; requested by and prepared for U.S. Senate Committee on Labor and Human Resources.

18. Newhouse J, Manning WG, Keeler EB, et al. Objective measures of health and prior utilization as adjusters for capitation rates. Health Care Financing Review 1989; 10(3):41-54.

19. Bishop C, Skwara KC. Recent growth of Medicare home health care. Health Affairs 1993; 12(3): 95-108.

20. Shindul-Rothschild J. The future of nursing education and employment in Massachusetts. Report to the Massachusetts Nurses Association. Boston, 1985.

21. Shindul-Rothschild J. The impact of competition and regulation on nursing care in Massachusetts hospitals: a report of preliminary findings. Testimony to Massachusetts Senate Committee on Post-Audit and Oversight; 1993.

22. Personal communication, Andrew Dreyfus, Director of Public and Community Relations, Massachusetts Hospital Association, January 1994.

23.National Association of Public Hospitals: "Defining Essential Community Provider", pp. 1-2.

24.Pallarito K: "Going Public", Modem Health Care,October 18, 1993, p.31.

25. "The Contribution of Academic Health Centers to Clinical Research"

26.New England Board of Higher Education: Biomedical Research and Technology, " Commission on Academic Medical Centers and the Economy of New England".

27. The Commonwealth Fund, Report of the Task Force on Academic Health Centers: "The Contribution of Academic Health Centers to Clinical Research".

28. Personal communication, Tony Santangelo, Director, Boston Organization of Teaching Hospital Financial Officers, January 1994.

29. Mansfield E. Academic research underlying industrial innovations: sources and characteristics. In progress, 1994. 

30.Jaffe AB. Real effects of academic research. The American Economic Review December 1989: 957-970.

31. Avies N, Sciar ED. Report on the Economic Impact of Non-Profit Sector Sponsored Biomedical Research in the Metropolitan New York Region. Prepared for The Commission on Biomedical Research and Development; New York, NY; 1993.

32. A Coalition of Massachusetts Teaching Hospitals induding the Boston Organization of Teaching Hospital Financial Officers: White Paper on "Health Care Reform and Teaching Hospitals"-Draft \#4, January 18,1994. Teaching hospitals included in all White Paper estimates are: Bay State Medical Center, Beth Israel Hospital, Boston City Hospital, Boston University Medical Center, Brigham \& Women's Hospital, Camey Hospital, Children's Hospital, Faulkner Hospital, Massachusetts Eye \& Ear Infirmary, Massachusetts General Hospital, New England Deaconess Hospital, New England Medical Center Hospital, St. Elizabeth's Medical Center of Boston and University of Massachusetts Medical Center 


